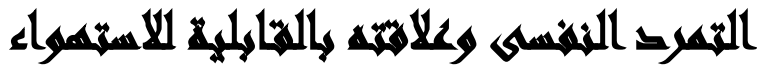

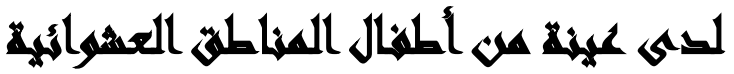

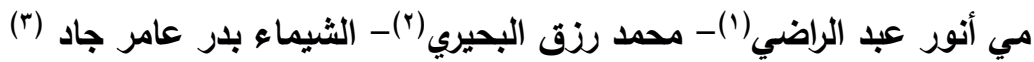

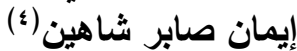

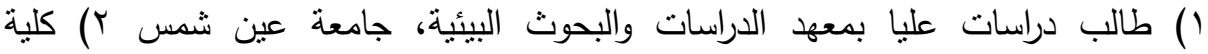

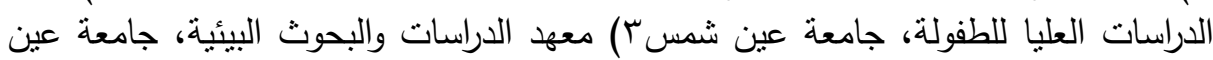
شمس ع) كلية البنات، جامعة عين شمس.

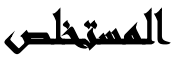

هدف هذا البحث إلى بحث العلاقة بين التمرد النفسى والقابلية للاستهواء لدى أطفال

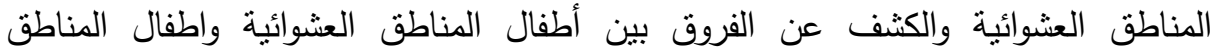

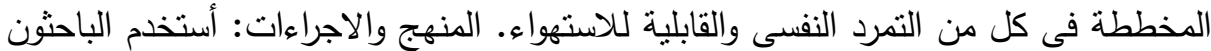

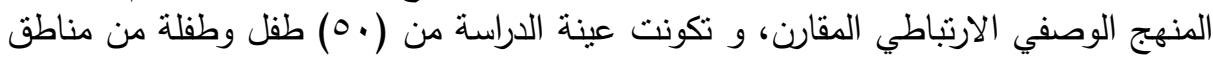

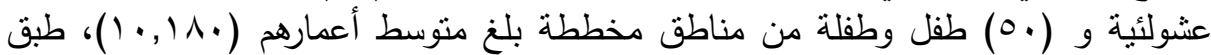
عليه مقياس التمرد النفسى (أعداد الباحثون) ومقياس القابلية للاستهواء (أعداد الباحثون)

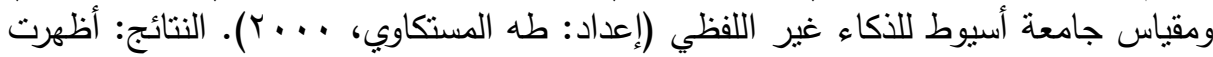

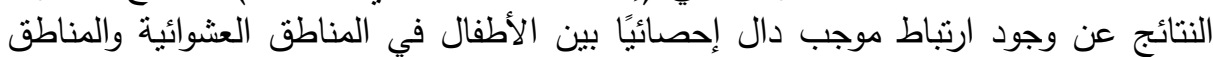

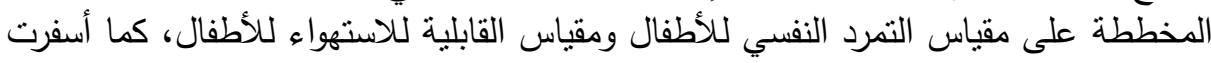

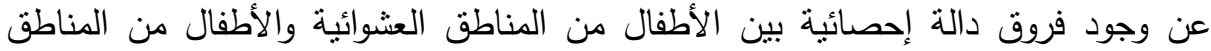

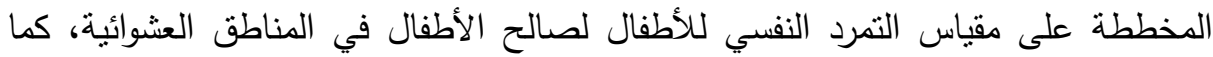

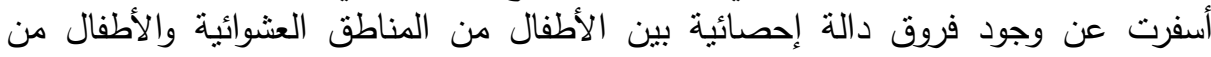
المناطق المخططة على مقياس القابلية للاستهواء للأطفال لصالح الألح الأطفال في المناطق

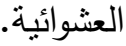

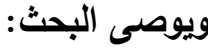

1 - قيام أجهزة الدولة بمراقبه ومراجعة وسائل الإعلام ومواقع التوصل الإجتماعى وما تبثه من قيم وأفكار واتجاهات للأطفال.

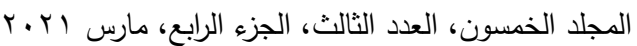

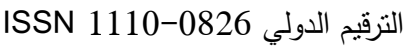


r- تتظيم برامج تدريبية للمعلمين في المدارس خاصاً المناطق العشوائية عن الأهتمام بالجانب

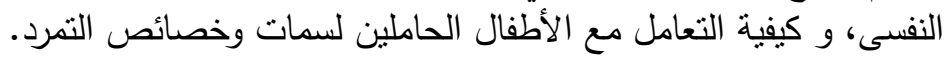

r- عقد دورات تدريبية للاختصاصيين النفسيين والاجتماعيين في المدارس عن كيفية النية علاج

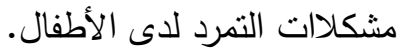

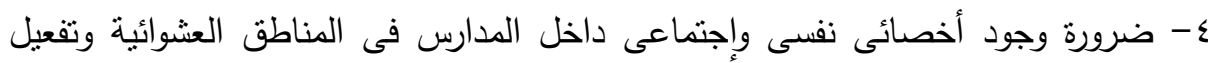

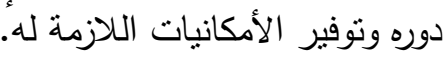

الكلمات الافتتاحية: التمرد النفسى ،القابلية للاستهواء ،أطفال المناطق العشوائية .

\section{xastax}

يواجه الأطفال أثناء نموهم بعض المشكلات التى تؤثر على عملية النمو وبناء شخصية

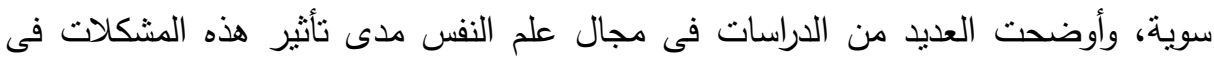
ظهور الاضطرابات النفسية والانحرافات السلوكية فى حياة الأطفال كما أن للبيئة المحيطة بالطفل وما تحمله من عوامل ثقافية واجتماعية واقتصادية متدنية وأساليب تتشئة غير سوية دور كبير فى ظهور العديد من المشكلات التى تعرض الطفل للمتاعب النفسية وافتقادهم

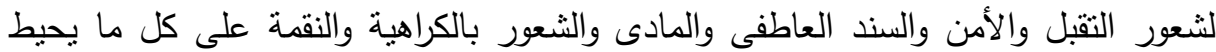
بهم، مما يولد لديهم ميول تمردية.

يرى بريم أن الثخص أثناء تمرده لا يكون على وعى بنى بالتمرد النفسي حيث إذا وعى

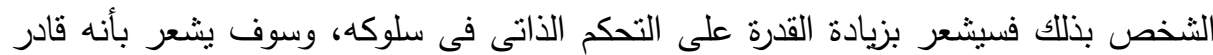

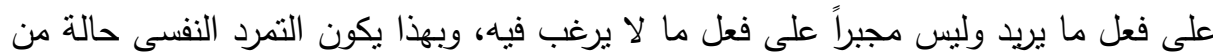

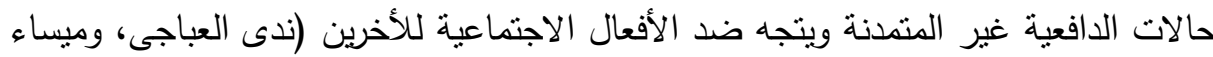

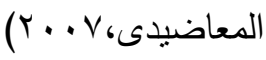

فى ظل هذا العصر الذى نعيشه والذى يتميز بالتعقيد والتغيرات السريعه والتوترات والضغوط النفسية تعد ظاهرة الاستهواء من تلك الظواهر الملاحظ تزايد حجمها وتضخم 
خطرها على أفراد المجتمع بصورة عامة والأطفال والمراهقين بصورة خاصة وهى قبول رأى او

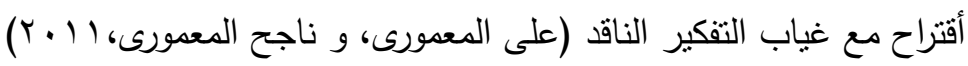

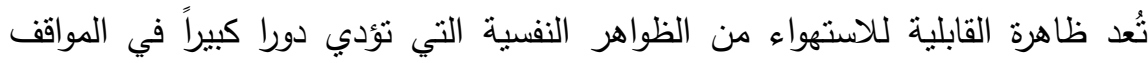

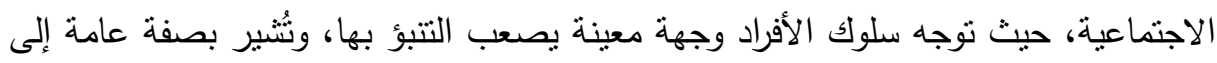

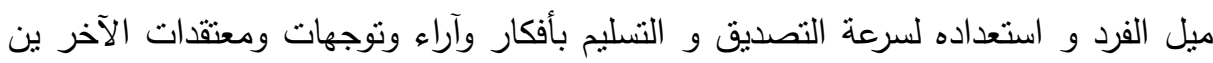

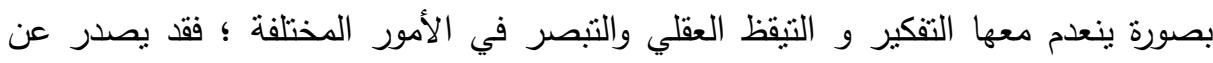
الفرد بعض السلوكيات غير المنطقية في أغلب الأحوال مما يجعله ضحية للهية الثنائعات والخرافات والرسائل الموجهة و المدمرة سواء التي تبنها بعض القنوات الفضائية ورسائل

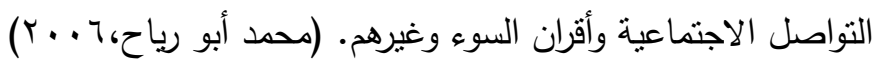

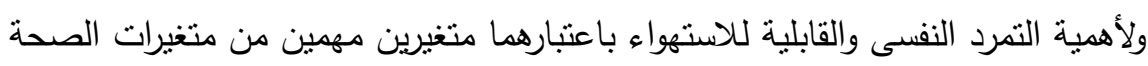
النفسية، جاءت هذه الدراسة للكثف عن العلاقة بين التمرد النفسى والقابلية للاستهواء.

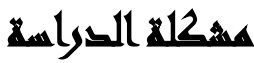

تكمن اهمية دراسة التمرد النفسى قى أرتباطها ببعض المشكلات السلوكية والاضطرابات

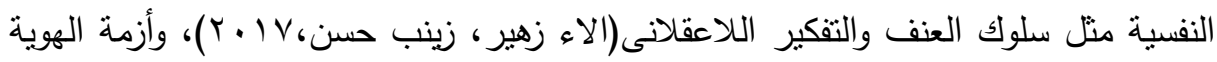

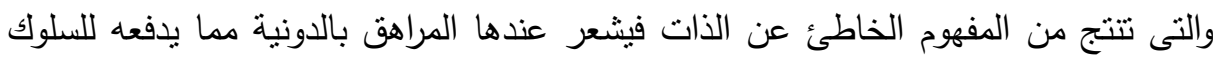
العوانى والجنوح وهذا يدفعه لإثبات نفسه وهويته من خلال التمرد على السلطة بجميع أنكالها

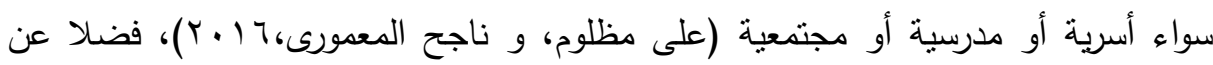

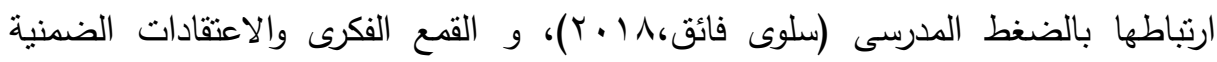

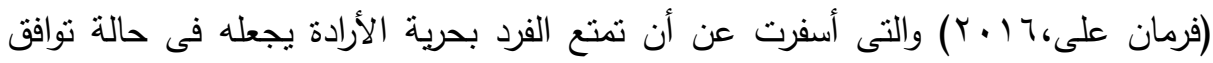

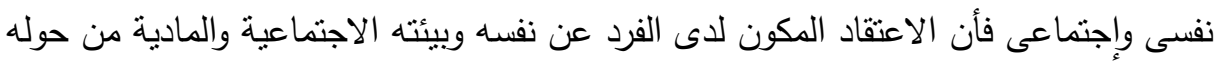

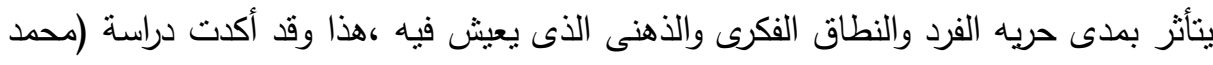

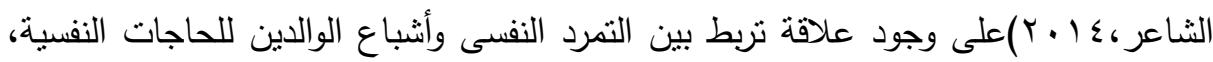


وكذللك ربط ( محمد يونس ، 10، ب بين الخبرات الصادمة التى يتعرض لها الفرد وبين التمرد

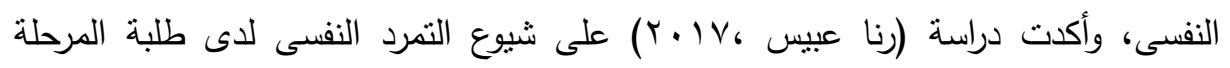

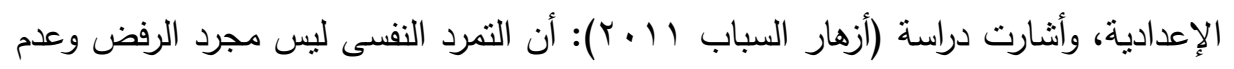

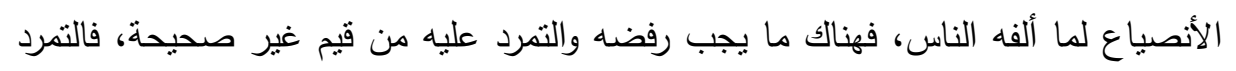

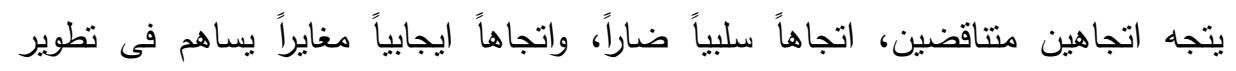
المجتمع والدفاع عن مصالحه وهو السبيل نحو تجديد الحياة وتطويرها. فيما يتصل بأهمية دراسة القابلية للاستهواء فهو التخوف من أن تصبح سمه أو متغير التهير من متغيرات الثخصية التي لاتكف عن نقل الأفكار السلبية واللاعقلانية والثائعات والمعتقدات الخاطئة لاى الأفراد، وبذلك فهي سمة من سمات سوء التوافق في الحياة والبيئة

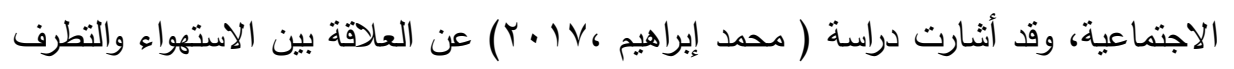

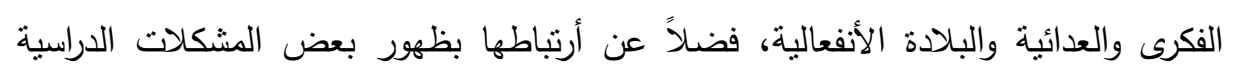

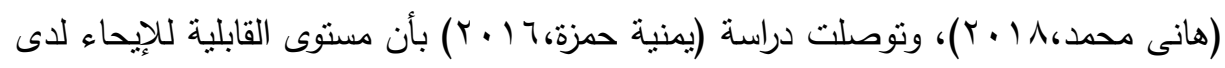
المراهق المتأخر دراسياً ليس بمنخفض، كما أن هناك علاقة بردية بين أدمان الأنترنت والقابلية

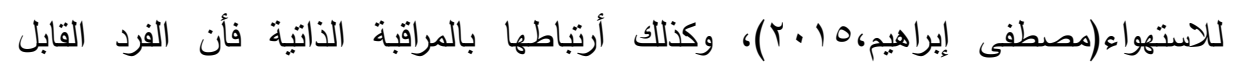
للاستهواء يميل إلى انخفاض فى المراقبة الذاتية وذللك لكونه لا يملك القدرة والوعى الكافى بلى الكئه

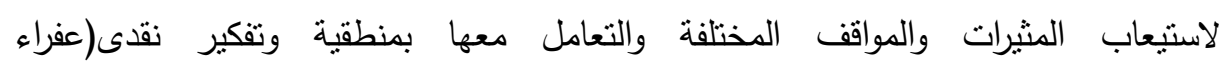

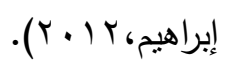
لندرة الدراسات السابقة - فى حدود علم الباحثة - التى تتاولت التمرد النفسى وعلاقته

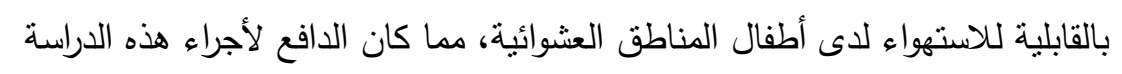
وتثير مشكلة الدراسة الأسئلة الآتية: ا. ما هي العلاقة بين التمرد والقابلية للاستهواء لدى عينة الدراسة من أطفال الدناطق الأق العثوائية؟ 


$$
\begin{aligned}
& \text { مجلة العلوم البيئية } \\
& \text { معهد الدراسات والبحوث البيئة - جامعة عين شمس لئس } \\
& \text { مي أنور عبد الراضي وآخرون }
\end{aligned}
$$

r. ما هو أثر متغير البيئة (عشوائية ومخططه) على مستوى التمرد نفسى لاى الاطفال فى

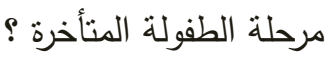

r. ما هو أثز متغير البيئة (عشوائية ومخططه) على مستوى القابلية للاستهواء لدى الاطفال فى مرحلة الطفولة المتأخرة؟ مئج

\section{أهمانهي التراسما}

$$
\text { تهدف هذه الاراسة في الأتي: }
$$

ا ـ الكثف عن العلاقة بين التمرد النفسي والقابلية للإستهواء لاى عينة الدراسة من الأطفال.

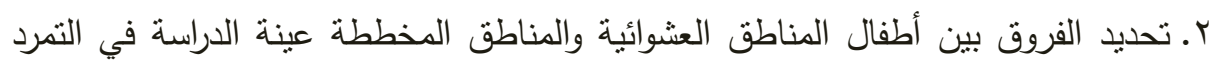
النفسي. r. المقارنة بين أطفال المناطق العشوائية والمناطق المخططة عينة الدراسة في القابلية

$$
\text { لإِستهواء. }
$$

\section{هروخ القواسما}

في ضوء أهداف الدراسة ونتائج الدراسات السابقة أمكن تحديد فروض الدراسة كما يلي: ا. يوجد ارتباط موجب دال إحصائيًا بين درجات عينة الدراسة من أطفال المناطق العشوائية على مقياسي التمرد النفسي والقابلية للاستهواء. r. نوجد فروق دالة احصائيًا بين متوسطات درجات عينتي من أطفال المناطق العشوائية والمناطق المخططة على مقياس التمرد النفسي. r.نوجد فروق دالة احصائيًا بين متوسطات درجات عينتي من أطفال المناطق العشودئية

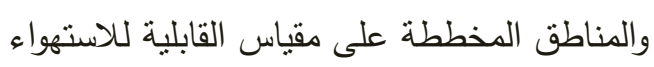

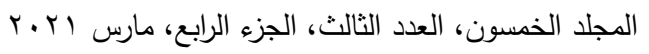

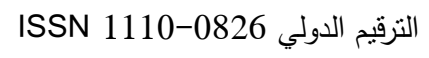




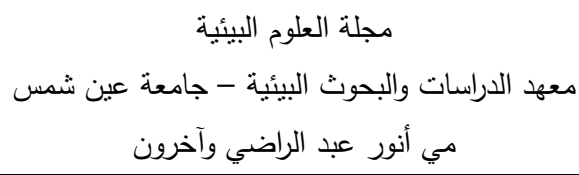

\section{هبور الدواسم}

ـالمحدات المكانية: قامت الباحثة بإجراء زيارة ميدانية لبعض الأماكن التي تتوافر بها عينة الدراسة وهذه الأماكن منطقة منشيه ناصر كمنطقة (عثوائية) ومنطقة مدينة نصر كمنطقة مخططة. ـالمحدات الزمنية: أجريت الدراسة بداية من شهر مارس 19 بـ و حتى نهاية يناير .$r \cdot r$.

\section{منهمج السواسم}

اعتمدت هذه الدراسة على المنهج الوصفي الارتباطي المقارن؛ الارتباطى بدراسة العلاقة

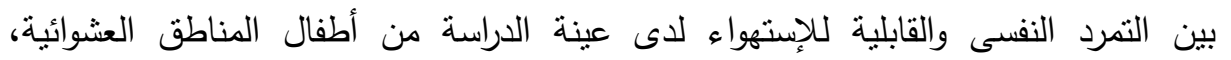
والمقارنة وذلك للمقارنة بين أطفال المناطق العشوائية والمخططة فى التمرد النفسى والقابلية

للإسنتهواء.

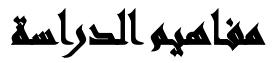

• تعريف التمرد التفسى: عرفته ياسرة ابو هدروس (•(ب): "بأنه مجموعة من السلوكيات المعبرة عن رفض المراهق لمحاولات تقييد حريته الفكرية والسلوكية التى تقع ضدن ثلاثة أبعاد هى: حريه الاختيار للسلوك، وتقبل النصح، وردود الافعال النفسية

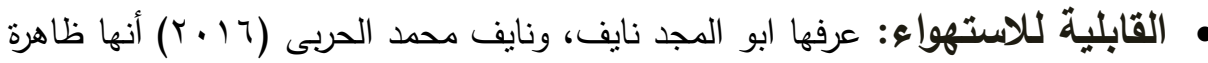
نفسية يمر بها كل أنسان ولكن بدرجات متفاوتة، إلا أن أرتفاع درجة القابليه للاستهواء يعبر عن سلوك غير سوى. 


$$
\begin{aligned}
& \text { مجلة العلوم البيئية } \\
& \text { معهد الدراسات والبحوث البيئية - جامعة عين شمس لئن } \\
& \text { مي أنور عبد الراضي وآخرون }
\end{aligned}
$$

\section{السراسايت الساريه}

أولاً: دراسات تناولت التمرد النفسى

ا ـ هدفت دراسة محمد يونس (10 ب ب) التعرف الى مستوى تعرض طلبه المرحلة الاعدادية

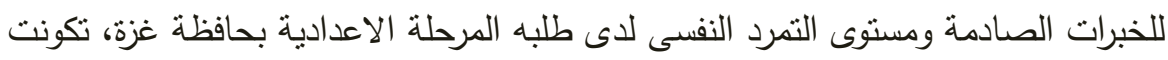

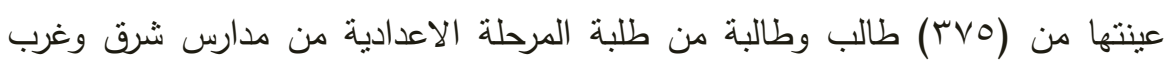
محافظة غزة، وأستخدم الباحث الادوات التالية: مقياس الخبرات الصادمة (إعداد برنامج

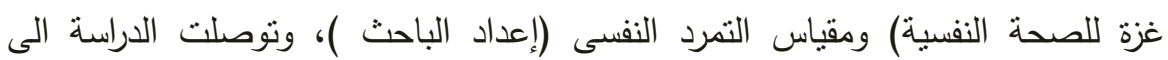
النتائج التالية: • أظهرت الدراسة وجود علاقة بين التصرد والخبرات الصادمة

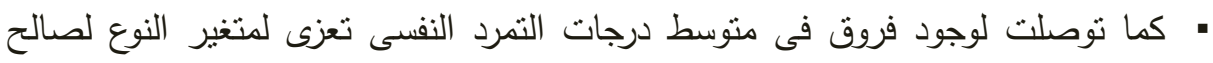
الاناث وكذللك منطقة السكن لصالح منطقه شرق غزة ولا توجد فروق فى منوسط الدرجات

$$
\text { فى التمرد النفسى تعزى لمتغير مستوى الدراسة. }
$$

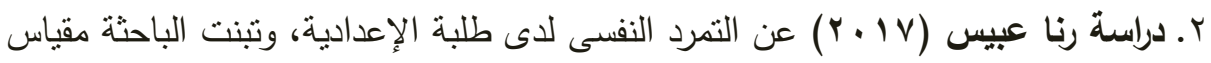

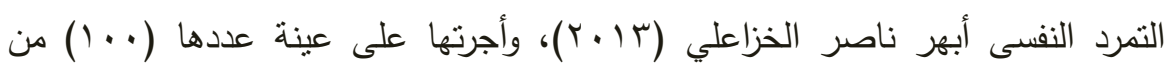

$$
\text { الذكور والإناث وأظهرت النتيجة ما يلى الثهر: }
$$

وجود فروق ذات دلالة إحصائية لشيوع التمرد النفسى لدى طلبة الأعدادية.

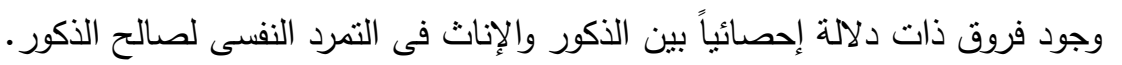

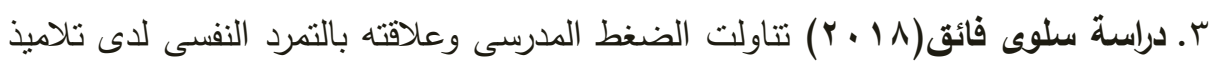

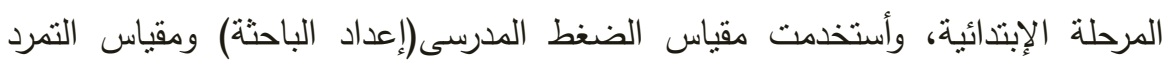
النفسى(إعداد الباحثة) على عينة قدرها ( · . (1) طالب وطالبة تم أختيارهم بالطريقة العشوائية، وأظهرت النتائج التالى: • عينة البحث لديهم ضغط مدرسى وتمرد نفسى والت

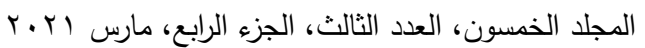

$$
\begin{aligned}
& \text { التزقيم الدولي 0826-08 1110 }
\end{aligned}
$$




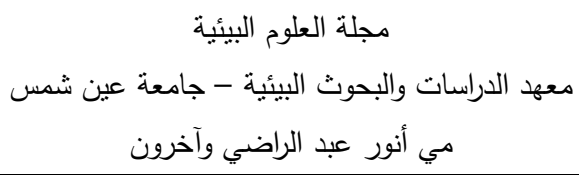

• وجود فروق ذات دلالة إحصائياً بين الذكور والإناث فى الضغط المدرسى لصالح الذكور

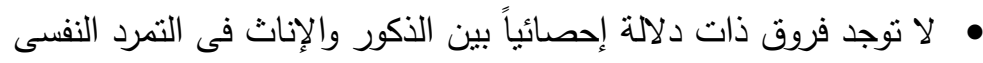

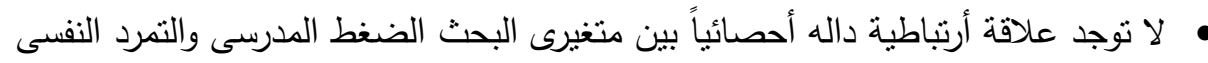

ثانيًا: دراسات تناولت القابلية للاستهواء دوبه

ا. دراسة يمنية حمزة (T ( ب) تحققت من مسنوى القابلية للإيحاء لاى المراهق المتأخر دراسياً، وكانت الدراسة تشمل على خمس حالات مقصودة هي حالات مراهقين

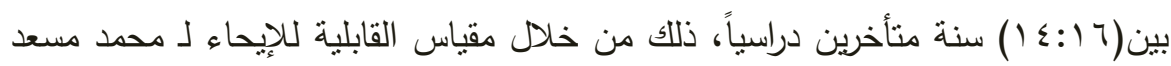

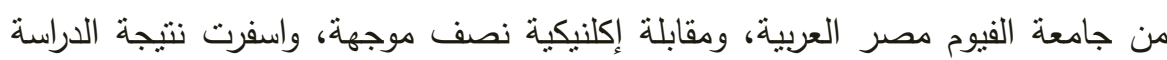

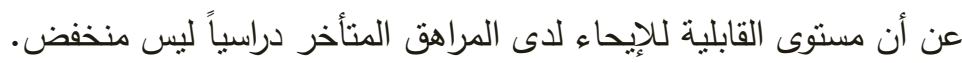
r. درسة أيمان عبد الرؤوف، وفاطمة الزهراء عبد الواحد (YlV) الفروق فى القابلية للأستقطاب الذهنى بين طلاب الجامعة مستخدمى شبكة التواصل الإجتماعى وفقاً لمتغير النوع، وكانت عينة الدراسة تنكون من (007) طالب وطالبة، وقد أعد الباحثتان مقياس لئن القابلية للأستقطاب، وقد توصلا إلى وجود فروق دالة أحصائياً وفقاً لمتغير النوع لصالح ونه اعنه

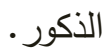

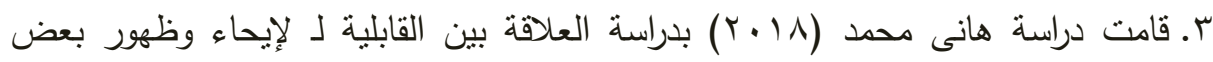

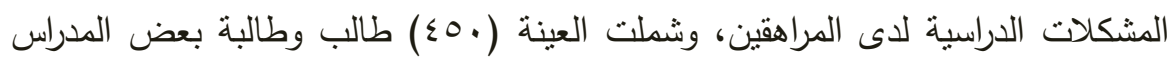

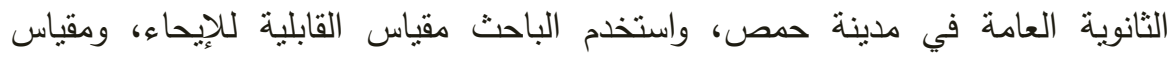
المشكلات الدراسية من إعداد الباحث، وتوصلت الدراسة إلى: • وجود علاقة إيجابية دالة إحصائيا بين درجات الطلبة على مقياس القابلية للإيحاء ككل وأبعاده الفرعية ودرجاتهم على مقياس المشكلات المدرسية. • توجد فروق دالة إحصائياً بين درجات الذكورو الإناث على مقياس القابلية للإيحاء ككل وأبعاده الفرعية لصالح الاناث. تعقيب على الدراسات السابقة: 
إن استقراء نتائج الدراسات السابقة يشير إلى ما يلي:

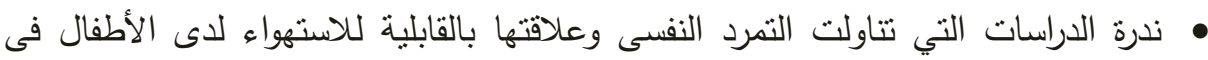
مرحلة الطفولة التأخرة -في حدود ما اطلعت علية الباحثة- في البحوث والدراسات العربية والأجنبية. • استعانت معظم الدراسات التي تتاولت التمرد النفسى أو القابلية للاستهواء بمقاييس كانت من إعداد مُعدي الدراسات. كثفت الدراسات السابقة وجود علاقة أرتباطية داله أحصائيا بين بعض المتغيرات (أسلوب النبذ والأهمال والقسوة وإثارة الإلم النفسى ـ القمع الفكرى والأعتقادات الضمنية ـ الأفكار اللاعقلانية _ صورة الذات ) والتمرد النفسى فى مراحل عمرية مختلفة. • كثفت العديد من الدراسات أن الذكور أكثر عرضده من الإناث للتمرد النفسى. • نتاولت الدراسات السابقة فئات عمرية مختلفة (طلاب جامعيين - طلاب مرحلة الابلة الأعدادية- المراهقين) مما يتضح للباحثة _ في حدود ما اطلعت علية الباحثة _ لم تتاول دراسة فئة الطفوله المتأخرة. • معظم الدراسات التى أجريت على القابلية للاستهواء لم نتتاول الفئة العمرية التى تتتاولها

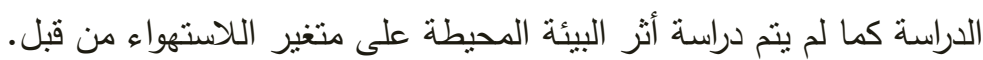
كثفت الدراسات السابقة وجود علاقة أرتباطية داله أحصائيا بين بعض المتغير التغيرات (إدمان الأنترنت _ التطرف الفكرى) والقابلية للاستهواء. • لم تتتاول أى من الدراسات التمرد النفسى والقابلية للاستهواء من خلاءل متغير البيئة. ندرة الدراسات التى تتاولت مرحلة الطفولة المتأخرة داخل البيئات العشوائية. 


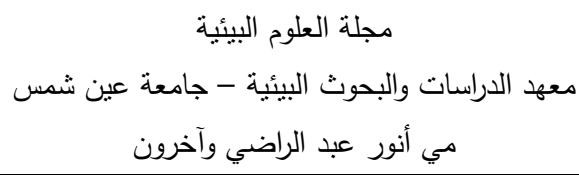

\section{الاطار النظليري للقراسة}

هناك العديد من النظريات التى تصلح لتفسير ظاهرتى التمرد النفسى والقابلية للاستهواء، اعتمدت الدراسة على نظرية اريكسون اتفسير التمرد النفسى لدى الأطفال فأدخل

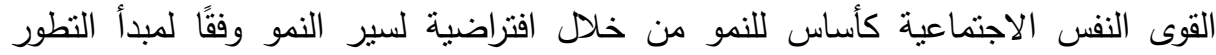

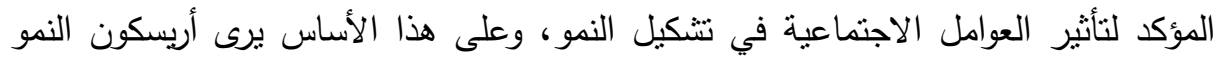

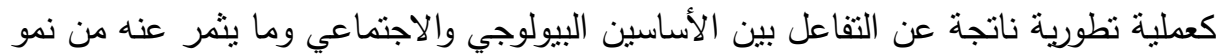
الثخص خلال مراحل العمر المختلفة، ويعتمد نمو الأنا في البداية على النتشئة الأسرية وفيما

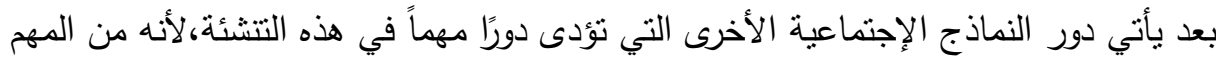
أن تسمح النتظيمات الإجتماعية الأخرى الموجودة لقدرات الطفل وطاقته بالتطور والنمو وتمثل أزمة هوية الأنا المطلب الأساسي للنمو ونقطة تحول نحو الاستقلالية الضرورية للنمو السوي

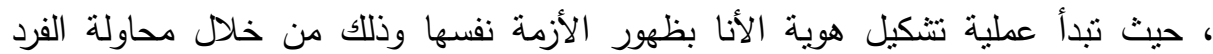
اكتتاف ما يناسبه من مبادئ ومعتقدات وأهداف وأدوار وعلاقات اجتماعية وتتتهي الأزمة

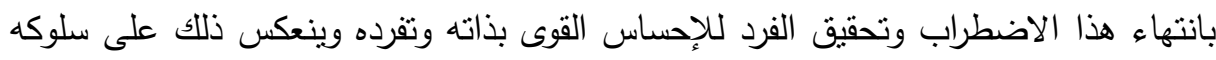
في التزامه بما اختاره وأيضًا بالمثل الاجتماعية بدلاً من مواجهتها.

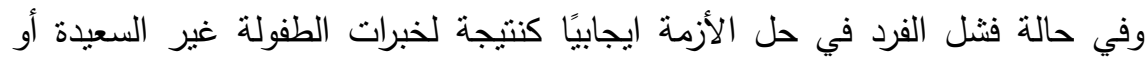
الظروف الاجتماعية المحيطة فهذا يؤدى لما يطلق عليه أريسكون أزمة الهوية التي تؤدى إلى الى لئه

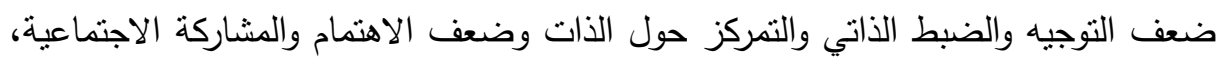

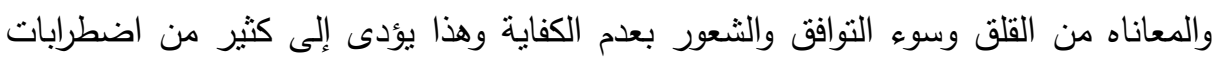

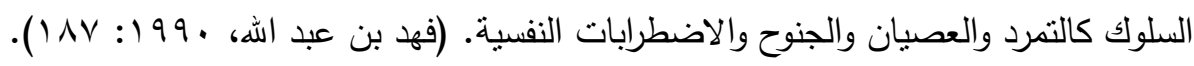
كما اعتمدت الدراسة على نظرية المناعة النفسية والتي ترى أن المناعة النفسية منظومة

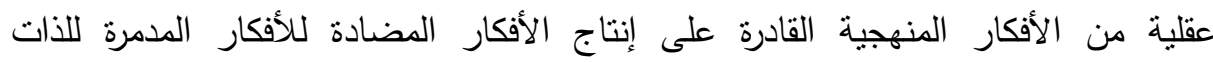
وللآخرين، وعندما لايقوم هذا الجهاز المناعي بوظائفه تظهر على الأفراد العديد من أعراض العادهار فقدان المناعة النفسية التي تعبر عن فقدان السبطرة الذاتية والتحكم الذاتي والاستسلام للفنشل 178

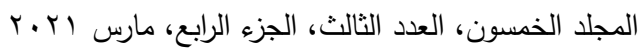

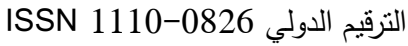




$$
\begin{aligned}
& \text { مجلة العلوم البيئية } \\
& \text { معهد الدراسات والبحوث البيئية - جامعة عين شمس لئ } \\
& \text { مي أنور عبد الراضي وآخرون }
\end{aligned}
$$

وخلل في معايير الحكم على الأشياء وارتفاع درجة ضعف النضج الانفعالي مما يسمح للأفكار الاستهوائية بالسيطرة على تفكير الفرد وهي غالبا ما تكون أفكار مدمرة يتبناها الفرد

$$
\text { أطلق عليها اسم الفيروس الفكري (ميرفت حشيش، ب . . ب). }
$$

كما اعتمدت الدراسة ايضاً على نظرية المجال حيث يرى "ليفين" أن هناك قوة نفسية

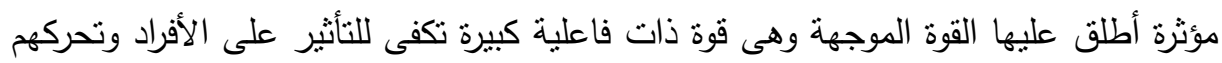
في اتجاه معين نتيجة وجودهم في منطقة مثيرة في المجال الذي يتواجدون فيه وهو بذللك يؤكد

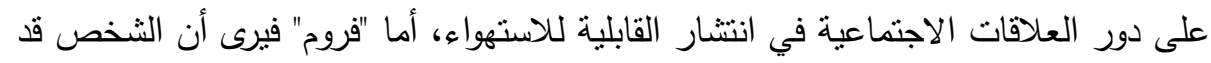
يتخذ استراتيجية الذوبان في الجماعة وعدم الخروج عنها نتيجة فقدانه لذاته المميزة المتفردة.

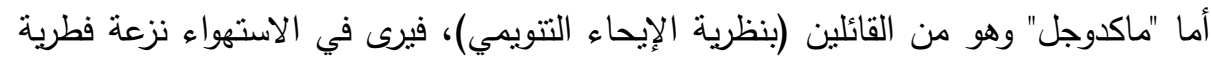
لاى الناس كافة وهو يظهر بصورة كبيرة حينما نسود حالة من المشاركة الوجدانية بين الأفراد

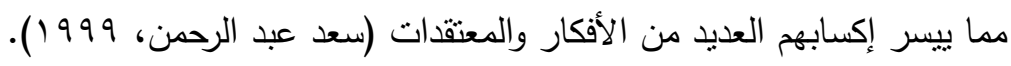
ويعتقد "كاتل" بأن النزعة إلى خضوع الذات دافئ دافع فطري يؤثر في نوجهات الأفراد

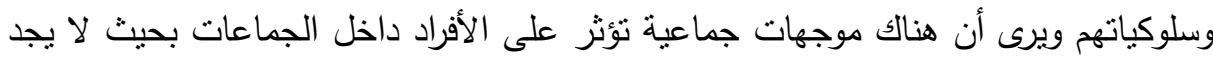

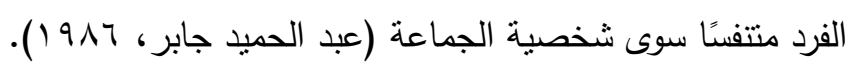

\section{إجراعاهي التراسمة}

() مجتمع العينة: تحدد مجتمع العينة من الأطفال فى مرحلة الطفولة المتأخرة ما بين (9-

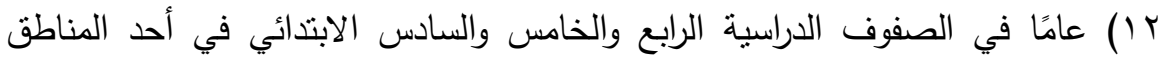
العشوائية تحديداً منطقة منشأة ناصر وأحد المناطق المخططة تحديدا منطقة مدينة نصر .

$$
\text { r) عينة الدراسة: عبنة حساب الكفاءة السيكومترية }
$$

$$
\begin{aligned}
& \text { المجلد الخمسون، العدد الثالث، الجزء الرابع، مارس IY الترقيم الدولي 0826-r } \\
& \text { ISSN 1110 }
\end{aligned}
$$


الأولهى: اشتملت على الأطفال فى مرحلة الطفولة المتأخرة(ن=.7) لحساب الكفاءة

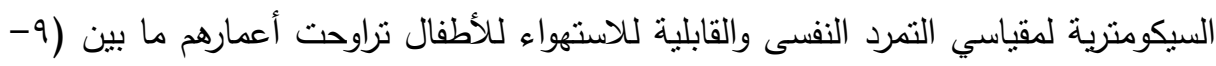
r ( )عامًا وذلك من نفس مناطق جمع العينة الأساسية(منشأه ناصر - مدينه نصر ).

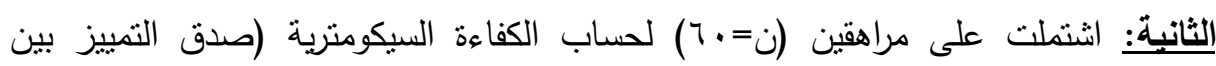

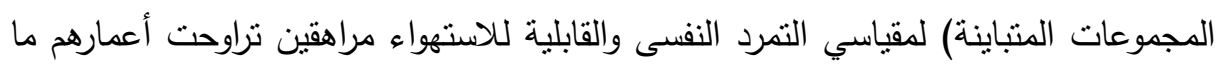
بين (rا10) عامًا وذلك من نفس مناطق جمع العينة الأساسية(منشأه ناصر - مدينه نصر). العينة الأساسية: اشتملت عينة الدراسة على (ن=.....) من الأطفال فى مرحلة الطفولة

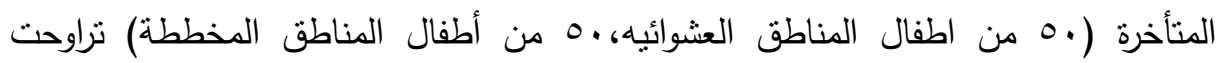

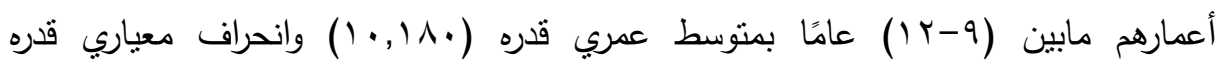

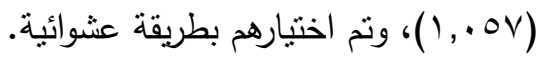

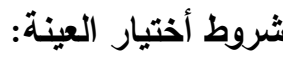
ا ـ أن يكون أفراد العينة من الذكور والإنهاث. r. أن يكون أفراد العينة لا يعانون من أى أعاقة. r. أن يكون أفراد العينة يعيشون مع والديهما. ع. أن يكون أفراد العينة مقيديين فى المدارس. 0. تم أستبعاد الأفراد الذين لا ينطبق عليهم شروط أختيار العينة.

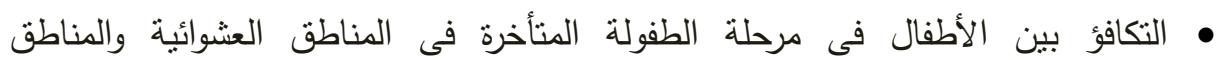

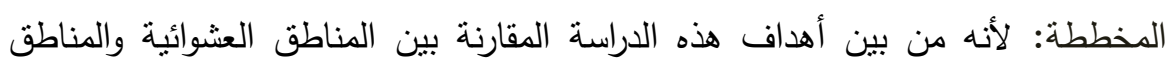

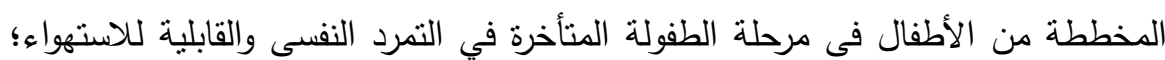

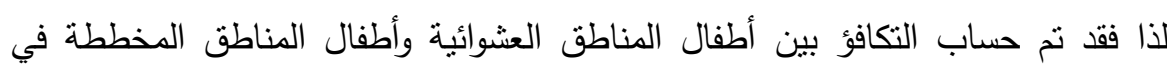
بعض المتغيرات التي قد تؤثر في نتائج الدراسة وذلك على النحو النحو التالي: التكافؤ بين عينتي من أطفال المناطق العشوائيه وأطفال المناطق المخططة فئ فئ العمر : 180

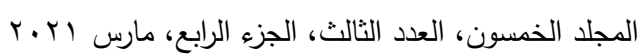

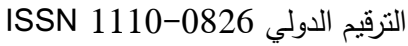




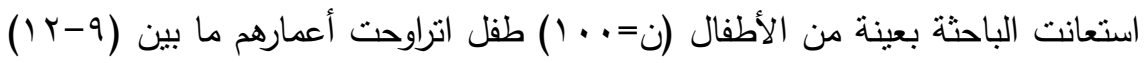

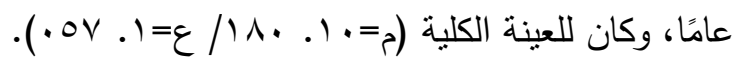
حسبت الباحثة التكافؤ بين الأطفال من المناطق العشوائية والأطفال من المناطق

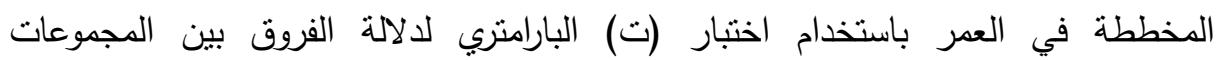

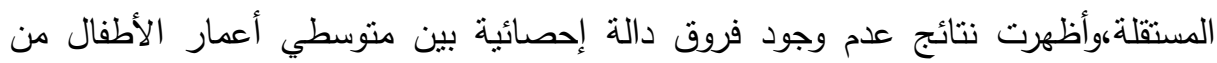

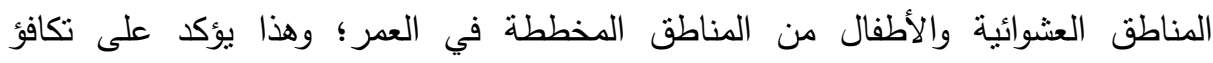
المجموعتين في العمر • - المن • التكافؤ بين مجموعتي الأطفال من المناطق العشوائية والأطفال من المناطق المخططة في الذكاء.

حسب الباحثون التكافؤ بين الأطفال من المناطق العشوائية والأطفال من المناطق المخططة في الذكاء باستخدام اختبار (ت) البارامتري لدلالة الفروق بين المجموعات المستقلة

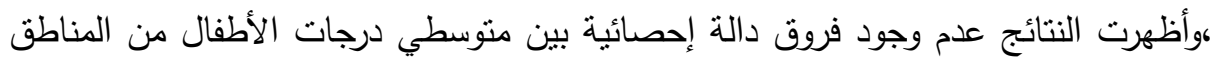

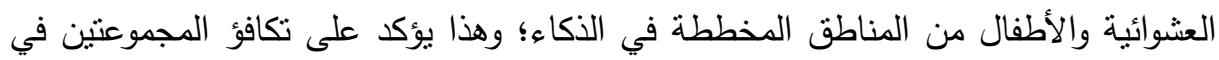

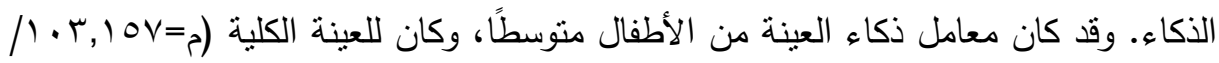
$\cdot(r, \uparrow \wedge 0=\varepsilon$ r) أدوات الدراسة: اعتمد الباحثون لتحقيق أهداف هذه الدراسة والتحقق من صدق فروضها

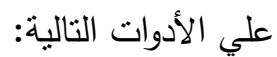
• مقياس التمرد النفسى للأطفال (إعداد: الباحثة). • مقياس القابلية للاستهواء للأطفال (إعداد: الباحثة).

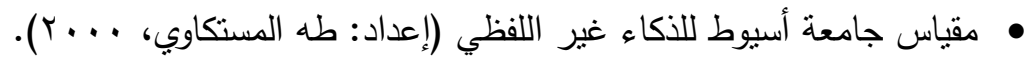
مقياس التمرد النفسى للأطفال: - معنه 
أولاً: ميرلت إعداد المقياس: أعده الباحثون بغرض توفير أداة سيكومترية لقياس التمرد

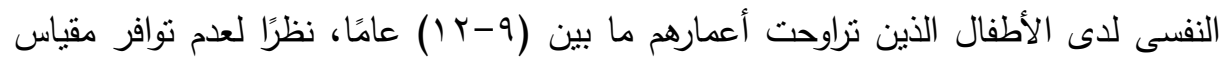
يتتاسب مع عينة الدراسة وخصائصها وكذلك المرحلة العمرية لها.

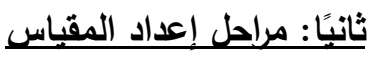
المرطلة الأوليم: الدراسة الاستطلاعية المكتبية: تضدنت الاطلاع على الدراسات السابقة

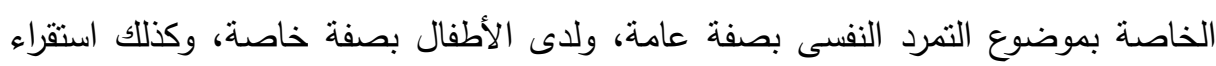

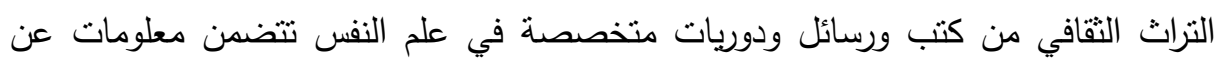

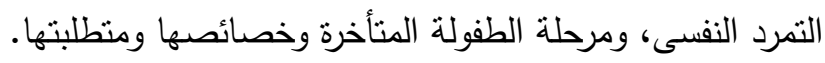
المرطلة الثانية: تحسب مكونات المقياس:تحددت مكونات المقياس من خلال عدة مصادر 1 ـ استقراء التراث النظري النفسي والإطلاع على الدراسات السابقة. Y- مراجعة المقاييس التي أعدت من قبل حول التمرد النفسى كمقياس(أمنه عويد، داليا كاظم،

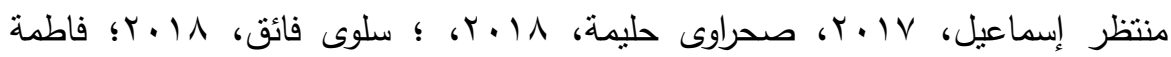

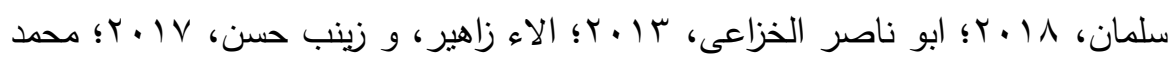

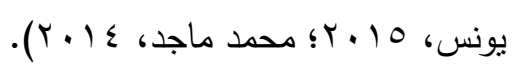

وبعد تحليل نتائج المصادر السابقة نم التوصل إلى مكونات كانت هي الأكثر شيوعًا بين

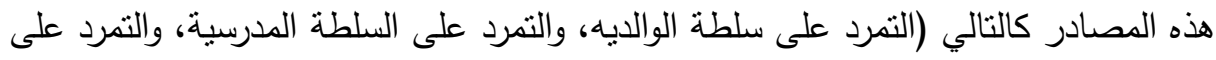
السلطة المجتمعية، وحرية التحكم الذاتي في السلوك). المرطلة الثاثثة: صباغة بنود المقياس: فى ضوء تحليل الأطر النظريه التى درست التمرد

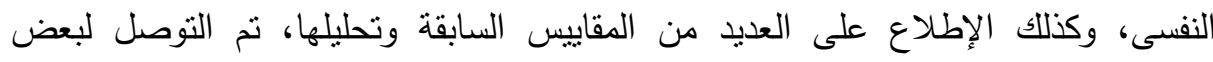
العبارات التى تم الأستعانه بها فى أعداد المقياس، بالإضافة إلى صياغة عنى عده عبارات جديدة

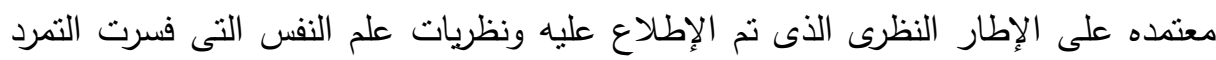
النفسى، وقد نم مراعاه أن يتم صياغة العبارات بالغه العربية الفصحى وأن تكون بسيطة الفئل 182

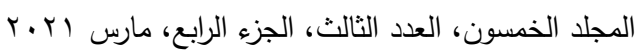

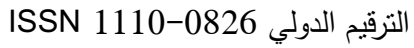


وواضحة لا تحتمل أكثر من معنى حتى تتمكن عينته الدراسة من فهمها، كما تم مراعاة أن لا

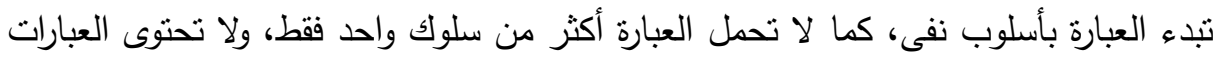

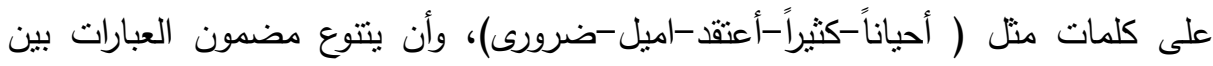
الايجاب والسلب، وقد بلغ عدد العبارات فى صورته الأولية (10) عبارة موزعه على أبعادة

المرطلة الرلابعة: صباغة المقياس بصوتته النهائبة: تكون المقياس فى صورته النهائية من

(Tr) عبارة تم توزيعهم على الأبعاد الأربعة للمقياس بعضها إيجابى وبعضها سلبى.

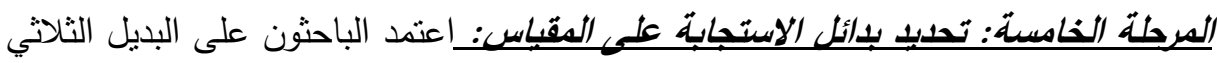

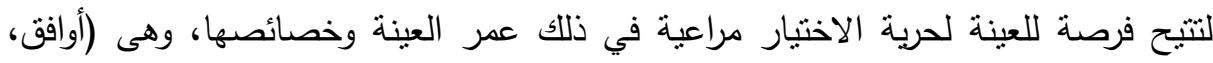

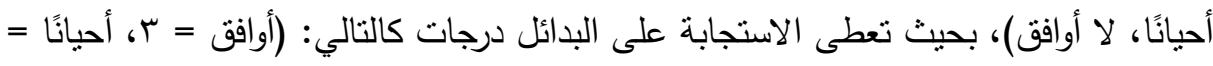
r، لا أوافق = ( ) وذللك حسب اتجاه صياغة البند من حيث الإيجاب والسلب وانعكاس البنود

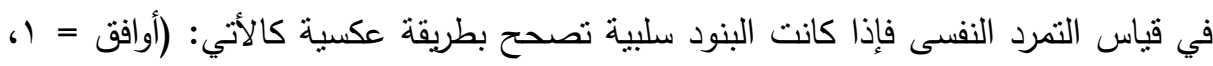

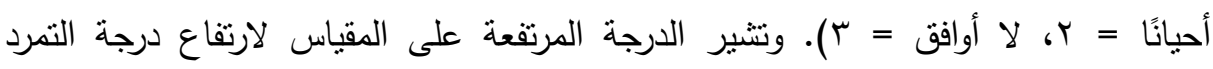
النفسى لاى الأطفال فى مرحلة الطفولة المتأخرة. المرطلة السادة: تعليمات المقياس: تضمنت تعليمات المقياس بيانات تعريفية عن (اسم

$$
\text { الطفل - النوع - السن - الصف الدراسي - اسم المدرسة). }
$$

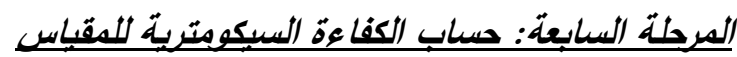

• ثبات المقياس: حسب الباحثون ثبات المقياس لعينة من الأطفال بطريقتن وذلك بأستخدام

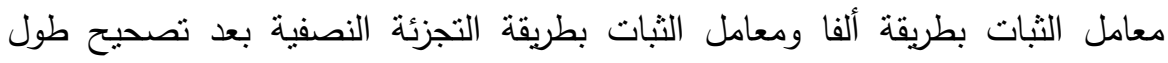
المقياس كانت قيمتهما أعلى من ( . . V)؛ ويوضح ذلك أن المقياس ثباته مقبول. • صلق المقياس: حسب الباحثون صدق التمبيز بين المجموعات المنباينة بين عينتي

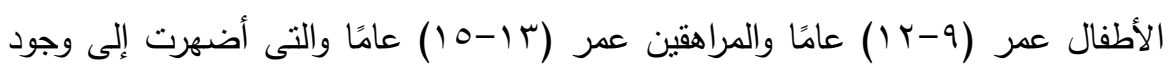

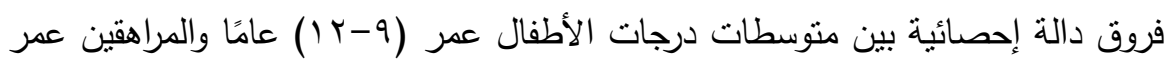

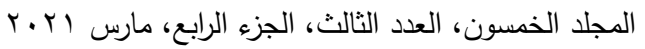

$$
\begin{aligned}
& \text { الترقيم الدولي 0826- ISSN 1110 }
\end{aligned}
$$




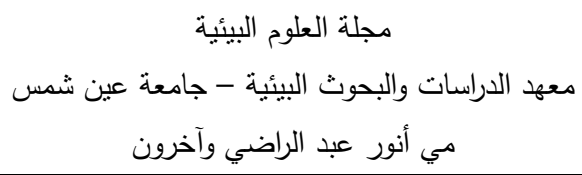

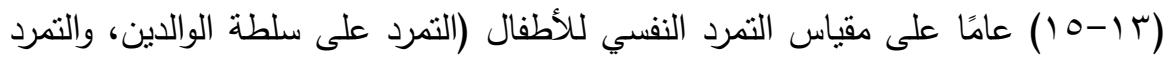

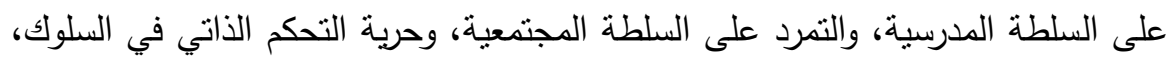

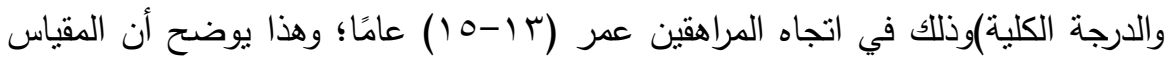
يتوافر فيه هذا الصدق.

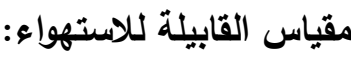

أولاً: مبريات إعداد المقياس: أعده الباحثون بغرض نوفير أداة سيكومترية لقياس القابلية

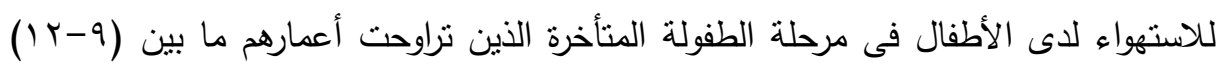
عامًا، نظرًا لعدم توافر مقياس يتتاسب مع عينة الدراسة وخصائصها وكذلك المرحلة العمرية

تُانيًا: مراحل إعداد المقياس المرطلة الأولهي: الدراسة الاستطلاعية المكتبية: تضدنت الاطلاع على الدراسات السابقة الخاصة بموضوع القابلية للاستهواء بصفة عامة، ولاى الأطفال بصفة خاصة، وكذلك استقراء التراث الثقافي من كتب ورسائل ودوريات متخصصة في علم النفس تتضمن معلومات عن القابلية للاستهواء والأطفال فى مرحلة الطفولة المتأخرة. المرطلة الثانية: تحديِ مكونات المقياس: تحددت مكونات المقياس من خلال عدة مصادر ا ـ استقراء التراث النظري النفسي والإطلاع على الدراسات السابقة.

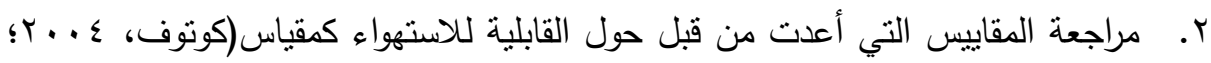

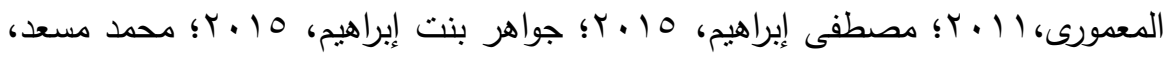

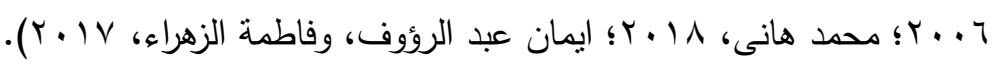

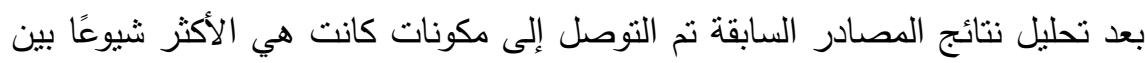

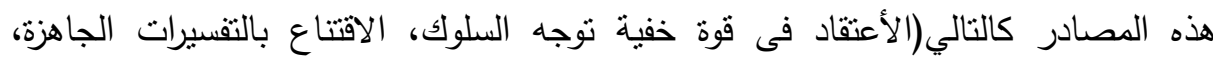
والخنوع، والمسايرة). 


$$
\begin{aligned}
& \text { مجلة العلوم البيئية } \\
& \text { معهد الدراسات والبحوث البيئة - جامعة عين شمس البهس } \\
& \text { مي أنور عبد الراضي وآخرون }
\end{aligned}
$$

المرطلة الثاثثة: صباغة بنولـ المقياس:فى ضوء تحليل الأطر النظريه التى درست القابلية

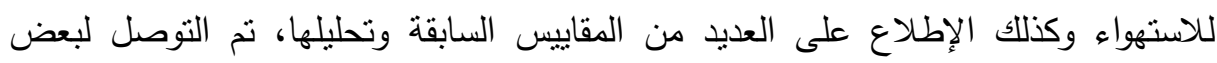

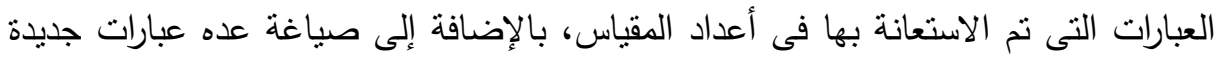

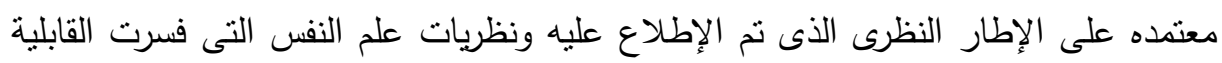
للاستهواء وقد تم مراعاة أن يتم صياغة العبارات بالغه العبية الفصحى وأن تكون بسيطة الإطن

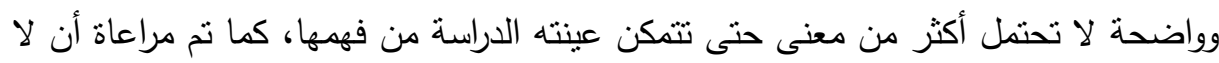

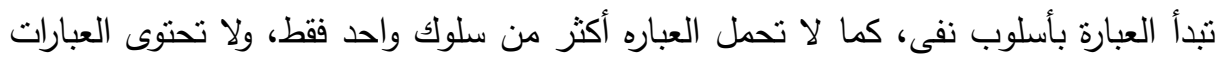

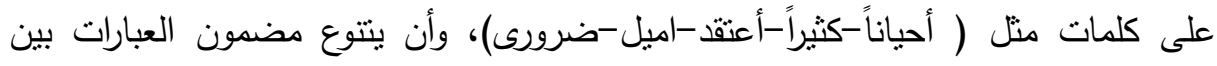
الايجاب والسلب، وقد بلغ عدد العبارات فى صورته الأولية (^^) عبارة موزعه على أبعادة الأربعة . الاجباب المرطلة الرلبعة: صباغة المقياس بصويته النـيائبة: تكون المقياس فى صورته النهائية من

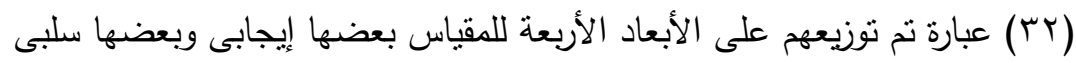
المرطلة الخامسة: تحدبا بائل الاستجابة على المقياس: اعتمد الباحثون على البديل الثلاثي لتنيح فرصة للعينة لحرية الاختيار مراعية في ذلك عمر العينة وخصائصها، وهى (أوافق،

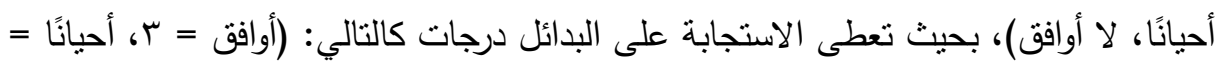

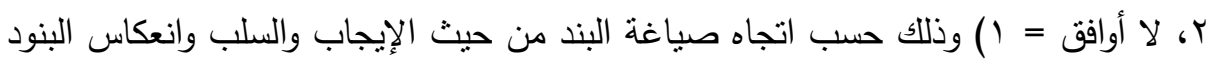

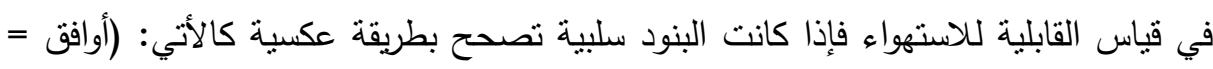

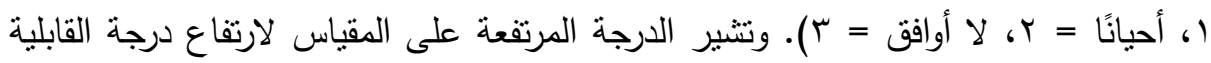
للاستهواء لدى الأطفال فى مرحلة الطفولة المتأخرة.

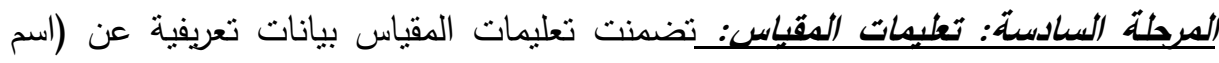
الطفل - النوع - السن - الصف الدراسي - اسم المدرسة) المرحلة السابعة: حساب الكفاعة السيكومتربية للمقياس العن

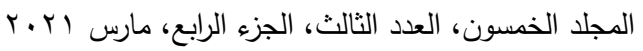

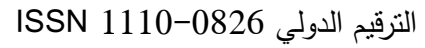


ا.ثبات المقياس: حسبت الباحثة ثبات المقياس لعينة من الأطفال بطريقتن بأستخدام معامل الثبات بطريقة ألفا ومعامل الثبات بطريقة التجزئة النصفية بعد تصحيح طول المقياس كانت قيمتهما أعلى من ( •. V)؛ ويوضح ذلك أن المقياس ثباته مقبول. r. صدق المقياس: حسب الباحثون صدق التمييز بين المجموعات المنباينة بين عينتي

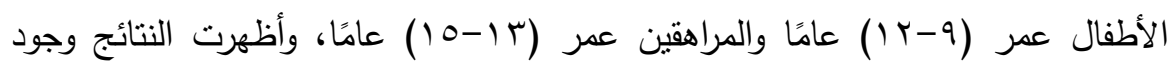

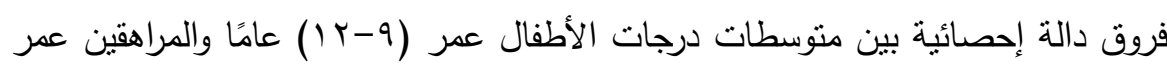

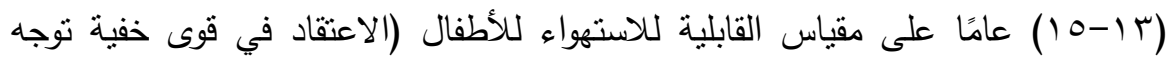
السلوك، والاقتتاع بالتقسيرات الجاهزة، والخنوع، والمسايرة، والدرجة الكلية) وذللك في اتجاه

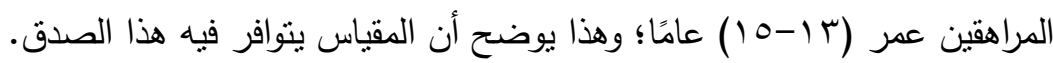

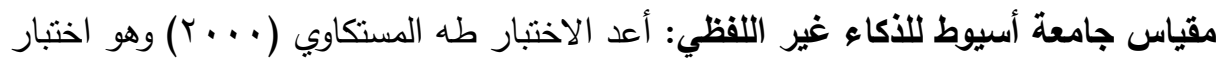
ذكاء جماعي يتكون من ( • ج) مفردة؛ يستخدم لتقدير القدرة العقلية العامة للأفراد الذين تتراوح

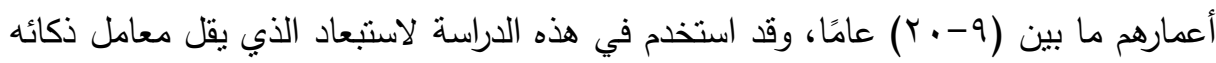

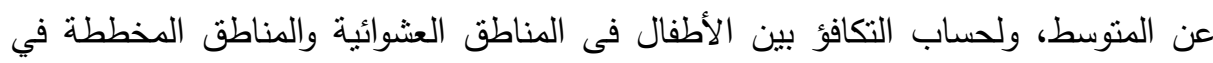

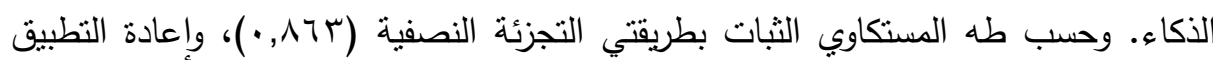
(qץr, ·). أما الصدق فحسبه بعدة طرق؛ الارتباط بالمحك (بعض الاختبارات الفرعية والدرجة الكلية لاختبار وكسلر - بلفيو لذكاء الراثدين والمراهقين) وتراوحت معاملات الارتبات بالارتباط

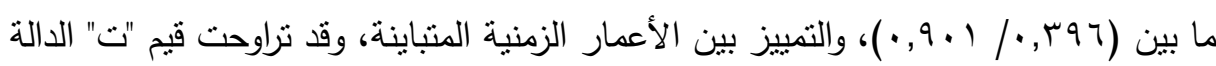

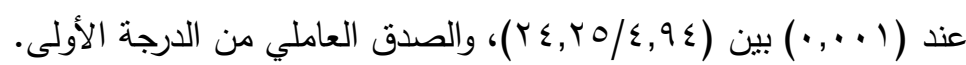
إجراءات تطبيق أدوات الدراسة:

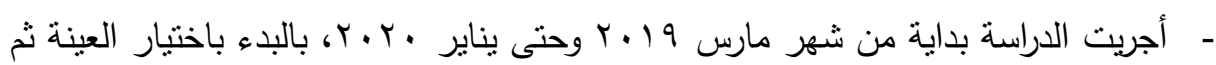

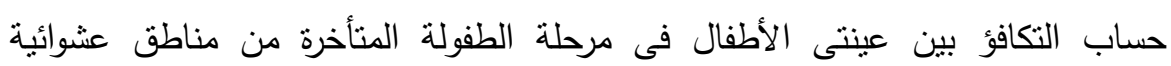
ومناطق مخططة على متغيرات الذكاء والعمر . 


$$
\begin{aligned}
& \text { مجلة العلوم البيئية } \\
& \text { معهد الدراسات والبحوث البيئية - جامعة عين شمس } \\
& \text { مي أنور عبد الراضي وآخرون }
\end{aligned}
$$

- متم تطبيق أدوات الدراسة على عينتى الأطفال فى مرحلة الطفولة المتأخرة من مناطق عثوائية ومناطق مخططة بصورة فردية في أماكن متفرقة (كالمكتبات العامة - الجمعيات الأهلية-الحدائق(، وروعي التطبيق على عينتى الدراسة بعد أقتناع تام بما يقوم به حتى فيه يكون بموافقتهم ورغبتهم الكاملة فى إبداء رأيهم ، وكان التطبيق لكل عينة في يوم منفصل.

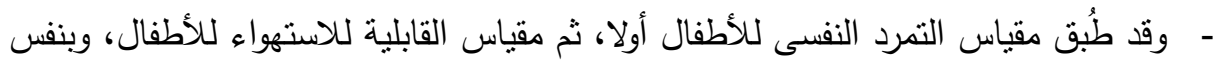

$$
\text { الطريقة. }
$$

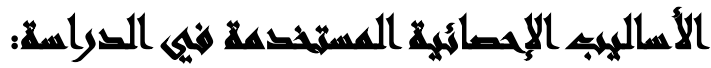

لتحقيق أهداف الدراسة والتحقق من صدق فروضها ويناء على حجم عينتها استخدم الباحثة الأساليب الإحصائية التالية:

- معامل ألفا لكرونباخ لحساب ثبات مقياسي التمرد النفسى للأطفال والقابلية للاستهواء للأطفال.

- معامل ارتباط بيرسون لحساب ثبات التجزئة النصفية مقياسي التمرد النفسى للأطفال والقابلية للاستهواء للأطفال، والتحقق من صدق الفرض الأول لتحديد طبيعة العلاقة بين التمرد النفسى والقابلية للاستهواء لاءى عينة الدراسة. - معادلة سبيرمان - براون لتصحيح طول المقياس في حساب معامل ثبات التجزئة النصفية لمقياسي مقياسي التمرد النفسى للأطفال والقابلية للاستهواء للأطفال. - اختبار (ت) البارامتري لدلالة الفروق بين المجموعات المستقلة لحساب صدق التمييز بين لئل

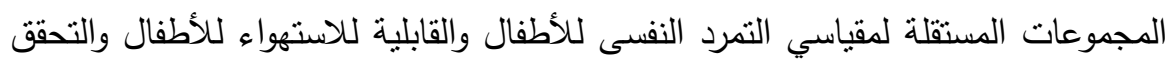
من صدق الفرضين الثاني والثالث في المقارنة بين الأطفال فى مرحلة الطفولة المتأخرة فى لئ المناطق العشوائية والمناطق المخططة في التمرد النفسى والقابلية للاستهواء.

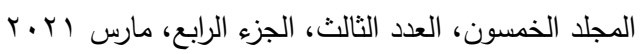

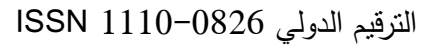




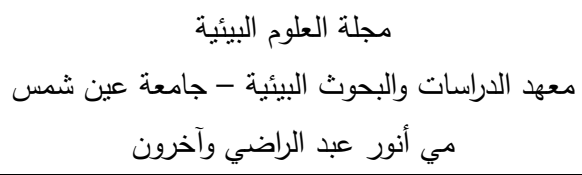

\section{نئائي السراهة}

الفرض الأول: ينص على "يوجد ارتباط موجب دال إحصائيًا بين درجات عينة الدراسة من أطفال المناطق العشوائية على مقياسي التمرد النفسي والقابلية للاستهواء". جدول(1): قيم معاملات الارتباط بين درجات عينة الدراسة من الأطفال في المناطق العشوائية

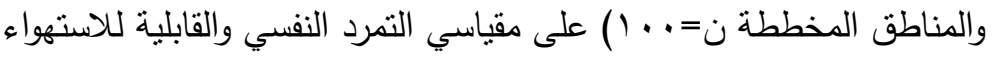

\begin{tabular}{|c|c|c|c|c|c|}
\hline الكلية للتمرد & 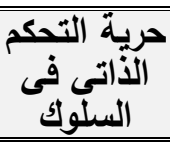 & التملطة المثلى & التمرد على الملية & التمرد على الولدين & البعد البع \\
\hline $0.784 * *$ & $0.749 * *$ & $0.836 * *$ & 0.836 ** & $0.768 * *$ & خفية توجهاد في قُوكي \\
\hline $0.769 * *$ & $0.763 * *$ & $0.847 * *$ & $0.799 * *$ & $0.773 * *$ & الاقتتاع بالتفسيرات \\
\hline $0.771 * *$ & $0.759 * *$ & 0.879 ** & 0.797 ** & $0.739 * *$ & الخنوع \\
\hline $0.780 * *$ & 0.774 ** & 0.836 ** & $0.769 * *$ & $0.719 * *$ & المسايرة \\
\hline $0.781 * *$ & $0.738 * *$ & $0.865 * *$ & $0.788 * *$ & 0.754 ** & لضبط الذاتل الذلية \\
\hline
\end{tabular}

أشارت نتائج جدول (1) إلى تحقق صدق الفرض الأول بوجود ارتباط موجب دال إحصائًًا بين درجات عينة الدراسة من الأطفال في المناطق العشوائية والمناطق المخططة

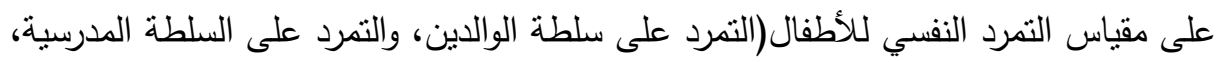

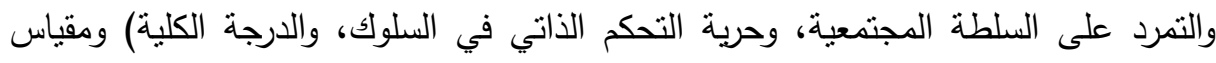

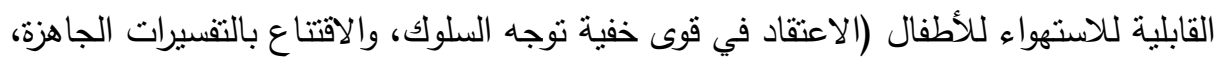
والتمرد على السلطة المجتمعية، وحرية التحكم الذاتي في السلوك، والدرجة الكلية) وذللك عند بلد بله

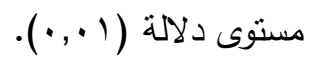

يمكننا تفسير هذه النتيجه بناء على ما أتفقت عليه الدراسات التى أجريت حول التمرد

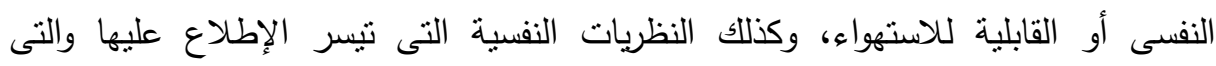

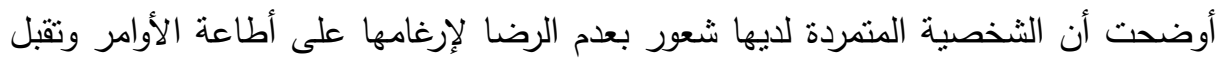




$$
\begin{aligned}
& \text { مجلة العلوم البيئية }
\end{aligned}
$$

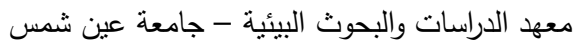

$$
\begin{aligned}
& \text { مي أنور عبد الراضي وآخرون }
\end{aligned}
$$

الإرشادات والنصح من ذوى السلطة، مما يجعله فى حالة تمرد سلبى يسعى لكسر القواعد

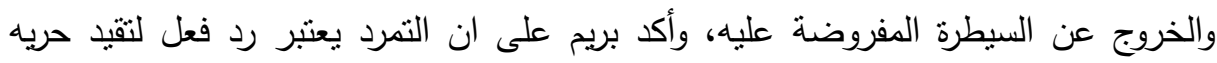

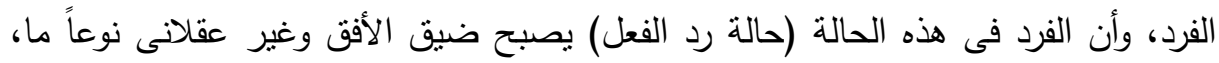

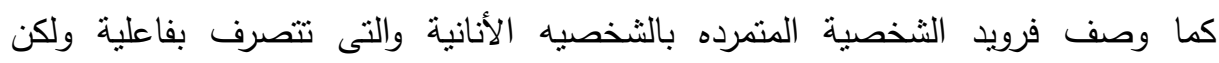
تصرفاتها نكون غير إجتماعية، وأرجع ذلك لغياب دور الأنا العليا والتى تمنل دور الضمدئ بندير والمرشد للفرد لما هو صواب وما هو خطأ، فإن روح التمرد تجعل الفرد فى حالة نفسية وعقلية

مشتتة.

من هنا يصبح الفرد فريسة سهلة للوقوع تحت تأثثر الاستهواء حيث أكد Canttril أن الفرد يصبح أكثر قابلية للاستهواء فى حالة أن يكون تفكيره وحالته العقلية غير ملائمة بدرجة

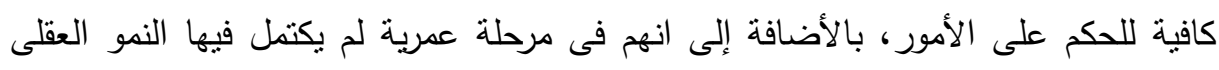

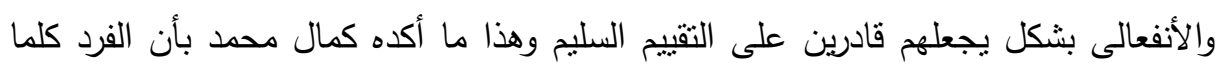

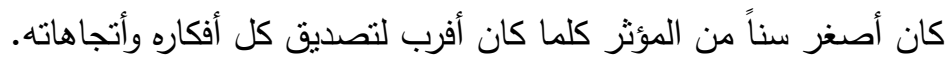

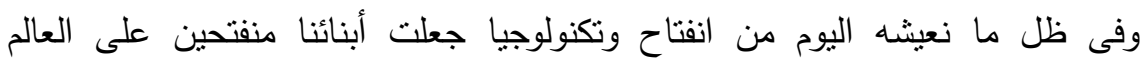
الخارجى، فنجدهم يستهون أفكاراً وأتجاهات معينه دون البحث أو التدقيق فيها والتى غالباً لا لانيات تتتاسب مع ثقافة مجتمعنا، باحثثن عن هويه مضاده للهويه التى رسمها لهم ذوى السلطة ومتخيلين أنهم وجدوا فيها تفردهم وأصبحوا مختلفين عن من حولهم وتمكنوا من تحقيق ذاتهم. 


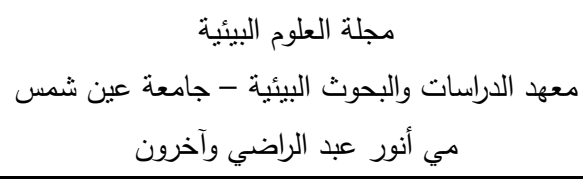

الفرض الثاني: ينص على "وجود فروق دالة احصائًًا بين متوسطات درجات عينتي من أطفال المناطق العشوائية والمناطق الدخططة على مقياس التمرد النفيسي".

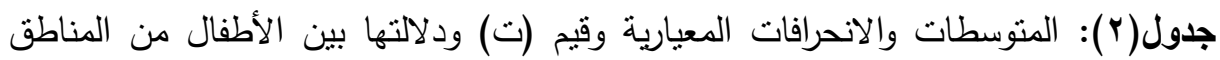
العشوائية والأطفال من المناطق المخططة على مقياس التمرد النفسي للأطفال

\begin{tabular}{|c|c|c|c|c|c|c|}
\hline الدالدوي & قَتَمة & الالانحرافي & المتوسط & ن & المجموعة & المتغير \\
\hline \multirow{2}{*}{0.01} & \multirow{2}{*}{3.306} & 2.812 & 15.920 & 50 & آطفال المناطق & \multirow{2}{*}{ سلطة الوالديني } \\
\hline & & 2.236 & 14.240 & 50 & آطفال المناطق & \\
\hline \multirow{2}{*}{0.01} & \multirow{2}{*}{3.434} & 2.654 & 15.660 & 50 & أطفال المناطق & \multirow{2}{*}{ التمرد على التطبة } \\
\hline & & 2.587 & 13.860 & 50 & آطفال المناطقة & \\
\hline \multirow{2}{*}{0.01} & \multirow{2}{*}{4.909} & 2.242 & 15.460 & 50 & أطفال المناطقة & \multirow{2}{*}{ التمجنطة على التمعية } \\
\hline & & 2.238 & 13.260 & 50 & آطفال المناطقة & \\
\hline \multirow{2}{*}{0.01} & \multirow{2}{*}{3.782} & 2.932 & 17.180 & 50 & آطفال العناطق العشية & \multirow{2}{*}{ الذرية التحكى فلى } \\
\hline & & 2.197 & 15.220 & 50 & أطفال المناطقة & \\
\hline \multirow{2}{*}{0.01} & \multirow{2}{*}{5.939} & 7.240 & 64.220 & 50 & آطفال المناطق & \multirow{2}{*}{ الدرجة الكلية } \\
\hline & & 5.507 & 56.580 & 50 & أطفال المناطقة & \\
\hline
\end{tabular}

أظهرت نتائج جدول (r) إلى وجود فروق دالة إحصائية بين متوسطات درجات الأطفال من المناطق العشوائية والأطفال من المناطق المخططة على مقياس التمرد النفسي للأطفال

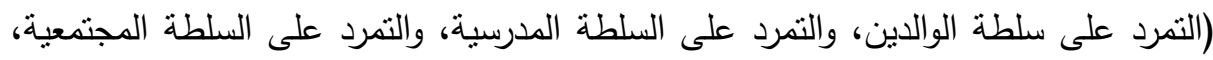

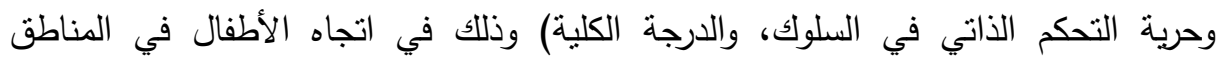

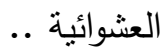
190

$$
\begin{aligned}
& \text { المجلد الخمسون، العدد الثالث، الجزء الرابع، مارس اY.r الترقيم الدولي 0826- } \\
& \text { ISSN 1110 }
\end{aligned}
$$




$$
\begin{aligned}
& \text { مجلة العلوم البيئية } \\
& \text { معهد الدراسات والبحوث البيئية - جامعة عين شمس لئن } \\
& \text { مي أنور عبد الراضي وآخرون }
\end{aligned}
$$

وبمقارنة هذه النتيجة بنتائج الدراسات السابقة التي تيسر الاطلاع عليها نلاحظ أنها

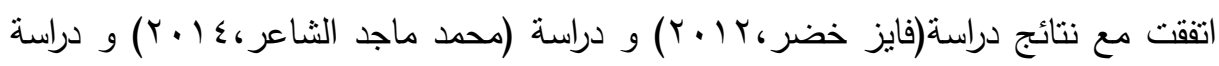

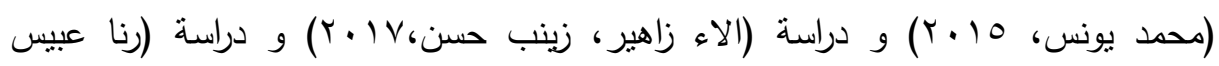

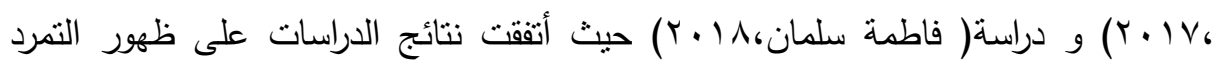
النفسى لاى أفراد عينتيها، وأن الفرد إذا أجبر على القام بسلوك معين حتى وأن كان راغباً فيه

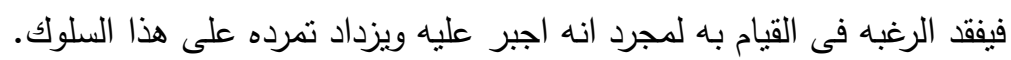
وتعزو الباحثة هذه الفروق بين أطفال المناطق العشوائية وأطفال المناطق المخططة

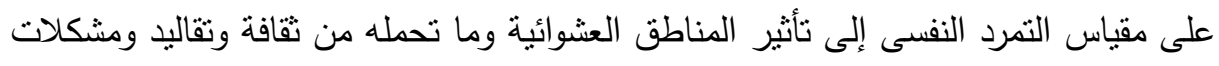
فىى القيم الإجتماعية ومشكلات فى المستوى التقافى والأقتصادى للأسرة، والتى تدعو الأسرة

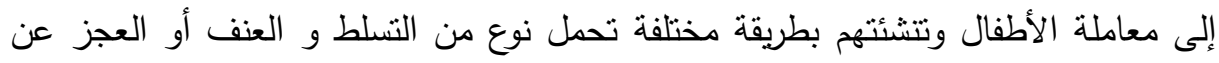

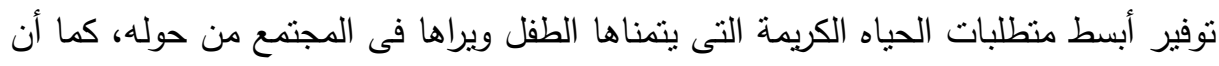

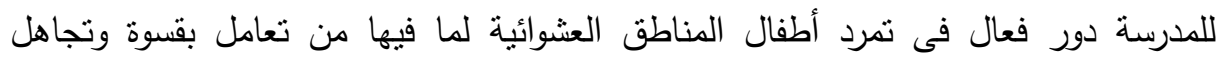
للمشكلات النفسية والإجتماعية التى يتعرض لها هؤلاء الأطفال والتى تؤثر على مستقبلهم

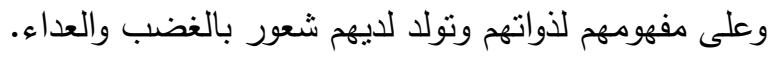




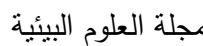

معهد الدراسات والبحوث البيئة - جامعة عين شمس لئس

مي أنور عبد الراضي وآخرون

الفرض الثالث: ينص على"وجود فروق دالة إحصائية بين متوسطات درجات الأطفال من المناطق العشوائية والأطفال من المناطق المخططة على مقياس القابلية للاستهواء للأطفال.

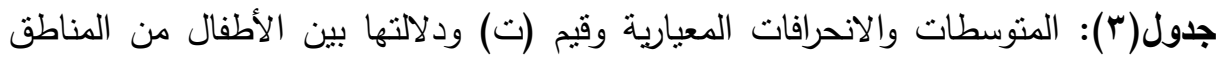
العشوائية والأطفال من المناطق المخططة على مقياس القابلية للاستهواء

لكأطفال

\begin{tabular}{|c|c|c|c|c|c|c|}
\hline الالاكتية & قَّمَة & الالمعرافي & المتوسط & ن ن & المجموعة & المتغير \\
\hline \multirow{2}{*}{0.01} & \multirow{2}{*}{3.381} & 2.623 & 17.120 & 50 & أطفال المناطق & \multirow{2}{*}{ الاعفية توجى فوى السلوك } \\
\hline & & 2.399 & 15.420 & 50 & آطفال المناطقة & \\
\hline \multirow{2}{*}{0.01} & \multirow{2}{*}{5.326} & 2.452 & 16.940 & 50 & أطفال المناطق & \multirow{2}{*}{ بالتفسيرات } \\
\hline & & 2.757 & 14.160 & 50 & آطفال المناطقة & \\
\hline \multirow{2}{*}{0.01} & \multirow{2}{*}{4.113} & 2.618 & 16.140 & 50 & أطفال المناطقة العشية & \multirow[b]{2}{*}{ الخنوع } \\
\hline & & 2.728 & 13.940 & 50 & أطفال المناطق & \\
\hline \multirow{2}{*}{0.01} & \multirow{2}{*}{5.555} & 2.638 & 16.240 & 50 & آطفال العناطق & \multirow{2}{*}{ المسايرة } \\
\hline & & 2.433 & 13.420 & 50 & أطفال المناطقة & \\
\hline \multirow{2}{*}{0.01} & \multirow{2}{*}{7.028} & 7.709 & 66.440 & 50 & أطفال المناطق & \multirow{2}{*}{ الدرجة الكلية } \\
\hline & & 5.651 & 56.940 & 50 & آطفال المناطقة & \\
\hline
\end{tabular}

أظهرت نتائج جدول (r) إلى وجود فروق دالة إحصائية بين متوسطات درجات الأطفال من المناطق العشوائية والأطفال من المناطق المخططة على مقياس القابلية للاستهواء للأطفال (الاعتقاد في قوى خفية نوجه السلوك، والاقتتاع بالتفسيرات الجاهزة، والخنوع، والمسايرة، والدرجة الكلية، والدرجة الكلية) وذلك في اتجاه الأطفال في المناطق العشوائية. 


$$
\begin{aligned}
& \text { مجلة العلوم البيئية } \\
& \text { معهد الدراسات والبحوث البيئية - جامعة عين شمس لئن } \\
& \text { مي أنور عبد الراضي وآخرون }
\end{aligned}
$$

أنفقت نتيجة هذا الفرض مع بنتائج الدراسات السابقة التي تيسر الاطلاع عليها

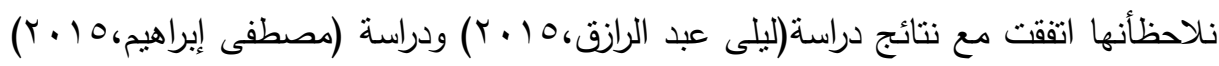

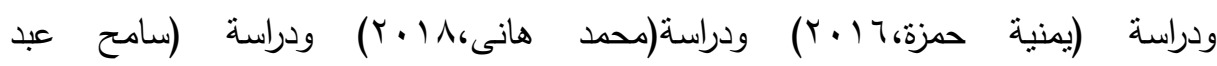

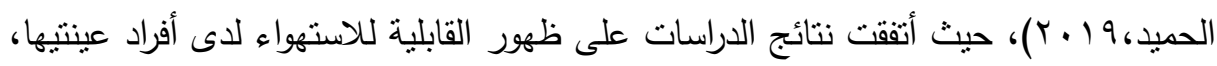

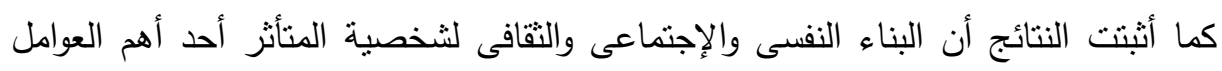
المؤثرة فى عملية الاستهواء. وأمكن تفسير نتيجة هذا الفرض في ضواء أن النهاء الأطفال فى المناطق العشوائية قد حصلو

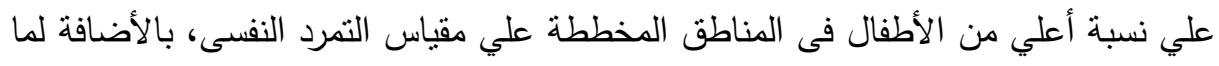

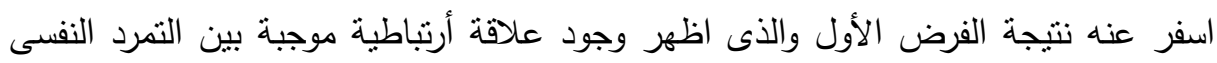
والقابلية للاستهواء. وتعزو الباحثه نتيجة هذا الفرض إلى ما تلعبة البيئة المحيطة بيهم من دور كبير فى

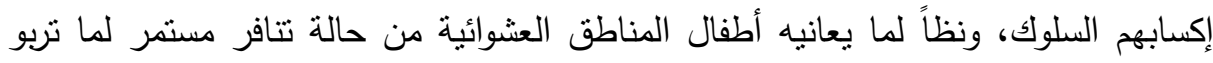

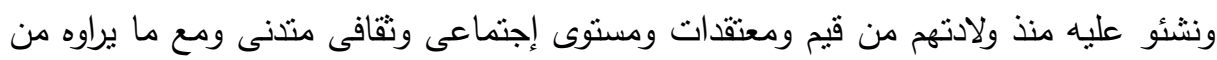

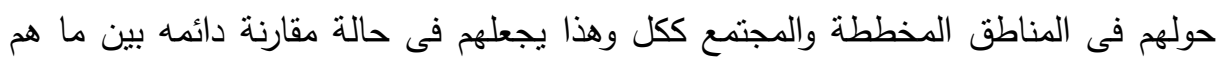
عليه وما حولهم، مما أفقدم المناعة النفسية اللازمه لصد أى أفكار أو أتجاهات إستهوائية،

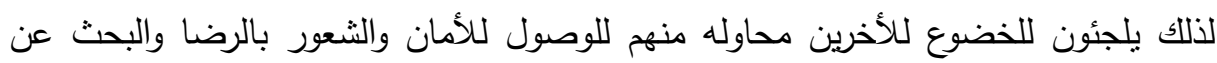

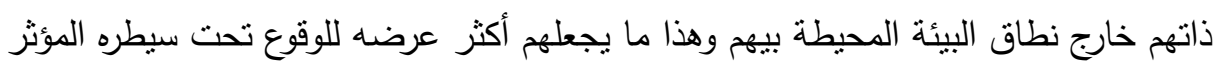

\section{تروسيامت التوراسمة}

توصي هذه الدراسة في ضوء نتائجها ونتائج الدراسات السابقة بضرورة ما يلي:

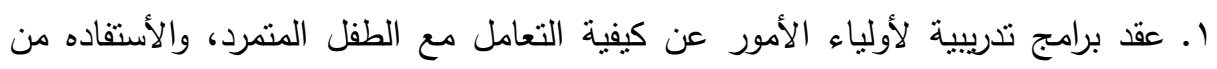

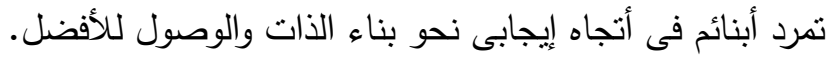

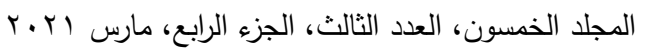

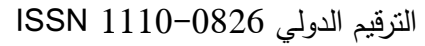


r. عقد ندوات بالمدارس عن خطورة الاستهواء والوسائل التى يستطيع الطفل أن يحمى بها نفسه من الوقوع تحت سيطرة المؤثرات. r. احتواء المناهج الدراسية بما ينمي التفكير الناقد لدى الأطفال لحمايتهم من الاستهواء.

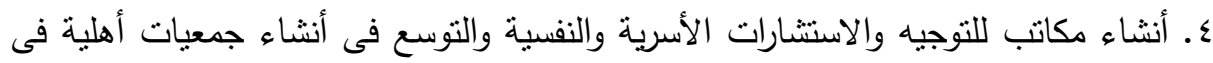
المناطق العشوائيه تهنم بالصحة النفسية للأطفال.

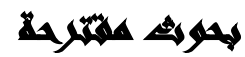

في ضوء ما تم التوصل إليه من نتائج اقترحت هذه الدراسة البحوث التالية: () فاعلية برنامج في تتمية التفكير العقلانى لدى عينة من الأطفال فى المناطق العشوائية. r) أعداد برنامج لرفع الطموح والدافعية للإنجاز لدى أطفال المناطق العشوائية وقياس أثرة ومدى فاعليتة.

r) أجراء دراسة حول التوافق النفسى والإجتماعى لأطفال المناطق العشوائية. \&) أجراء برنامج أرشادى علاجى لخفض ظاهرة التمرد النفسى السلبى لدى الأطفال.

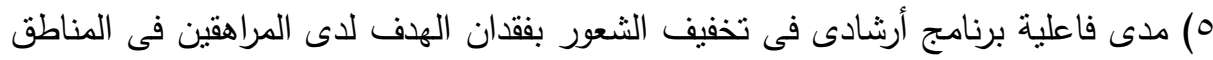
العشوائية. 7) أجراء دراسة عن العلاقة بين متغير هذه الدراسة القابلية للاستهواء ومتغيرات أخرى ( القلق القاه - أحترام الذات - الذكاء الأنفعالى). ( أجراء دراسة مماتلة للتعرف على ظبط الذات وعلاقته بالقابلية للاستهواء. ^) فاعلية برنامج لتخفيف القابلية للاستهواءلدى عينة من الأطفال فى مرحلة الطفولة المتأخرة. 


$$
\begin{aligned}
& \text { مجلة العلوم البيئية } \\
& \text { معهد الدراسات والبحوث البيئية - جامعة عين شمس لئن } \\
& \text { مي أنور عبد الراضي وآخرون }
\end{aligned}
$$

\section{zall}

الاء زهير ، وزينب حسن فليح الجبوري (Y V • Y Y): التمرد النفسي والتفكير اللاعقلاني وعلاقتهما

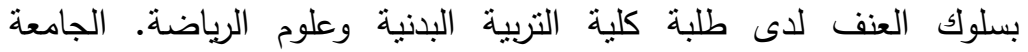

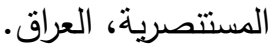

ابو المجد نايف الشوربجى، ونايف محمد حربى، تقنين مقياس أيوا للقابلية للإيحاء متعدد

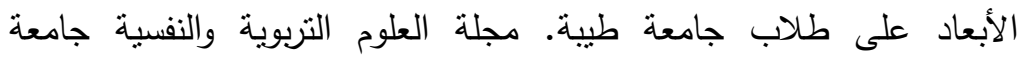

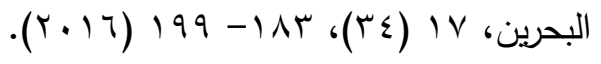

أزهار محمد عبد المجيد السباب. قياس التمرد النفسى عند طلبة معهد إعداد المعلمين تكريت.

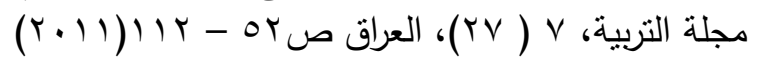

باربرا انجلر (999 (1): مدخل إلى نظريات الثخصية. ترجمة: فهد بن عبد الهه بن دليه.

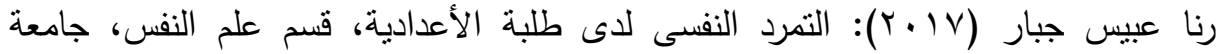

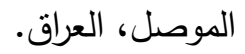

سعد عبد الرحمن السيد فؤاد (999 (1)): علم النفس الاجتماعي، رؤية معاصرة. القاهرة: دار الفكر العربي.

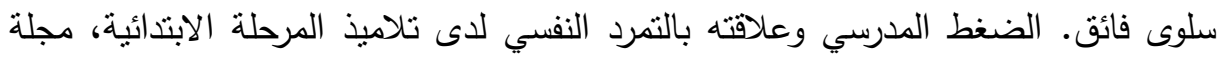

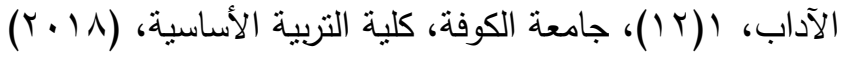

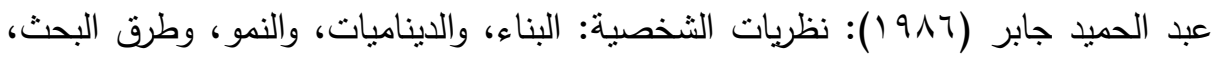
والتقويم. القاهرة: دار النهضية العربية.

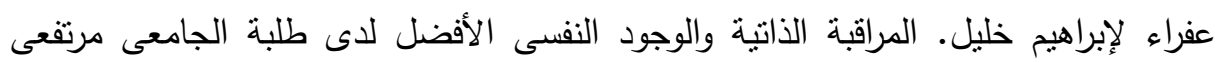

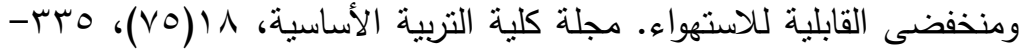

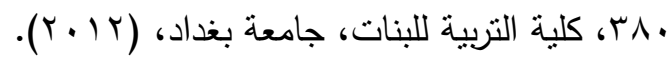

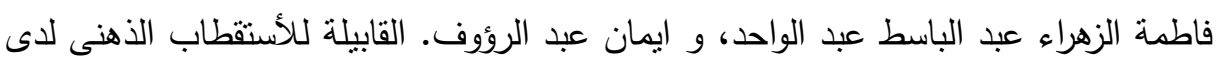

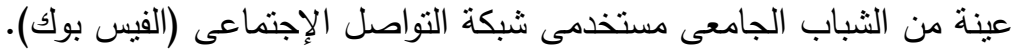

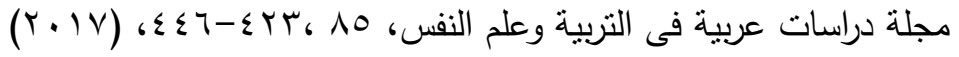

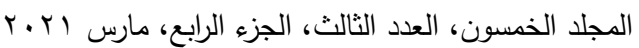

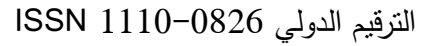


فرمان علي محمود (T 1 • ب): القمع الفكري والاعتقادات الضمنية عن الذات والعالم وعلاقتهما

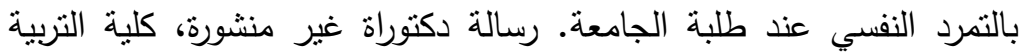
للعلوم الصرفة /ابن الهيثم، قسم العلوم التزبوية والنفسية، جامعة بغداد.

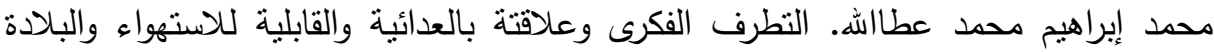

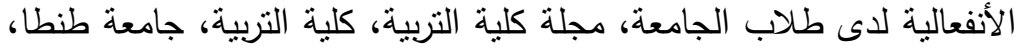

$$
\text { . (r. IV)، T } 4 \leqslant-09 r \cdot(r) T V
$$

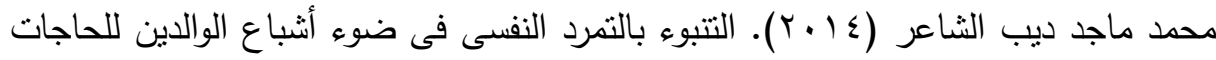

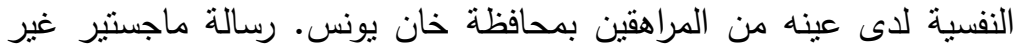

$$
\text { منشورة، جامعة الأقصر ، غزة الكن. }
$$

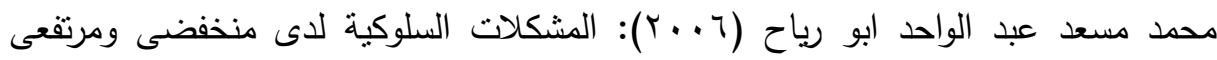

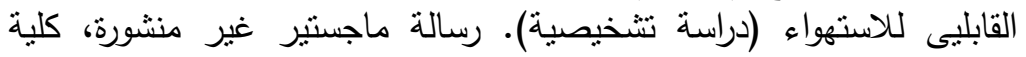

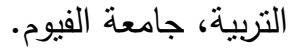

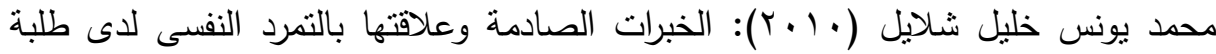
المرحلة الأعدادية بغزة. رسالة ماجستير غير منشورة، الجامعة الأسلامية ،غزة لاتئ

$$
\text { •فلسطين، }
$$

مصطفى إبراهيم احمد حسين (10 ب. ب): إدمان الأنترنت وعلاقته بالقابلية للاستهواء لدى

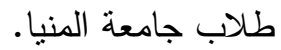

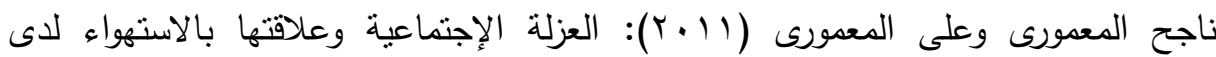
الأطفال. رسالة ماجستير غير منشورة، كلية التمريض جاعنة الإعة بابل.

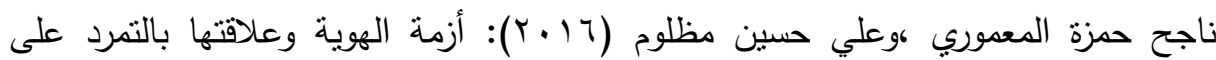

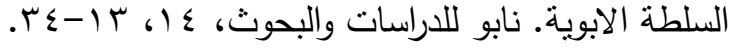

ندى فتاح العباجى وميساء يحى المعضيدى، قياس التمرد النفسى لدى طلابة المرحلة

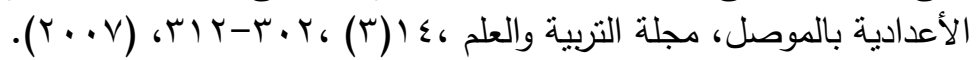

هانى محمد عبارة. القابلية للإيحاء وعلاقتها ببعض المشكلات الدراسية لدى المراهقين: دراسة

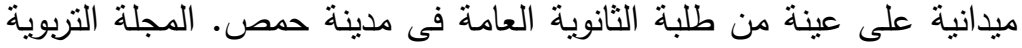

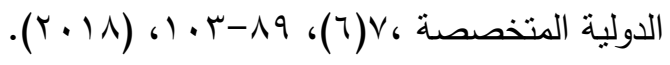




$$
\begin{aligned}
& \text { مجلة العلوم البيئية } \\
& \text { معهد الدراسات والبحوث البيئية - جامعة عين شمس البرس } \\
& \text { مي أنور عبد الراضي وآخرون }
\end{aligned}
$$

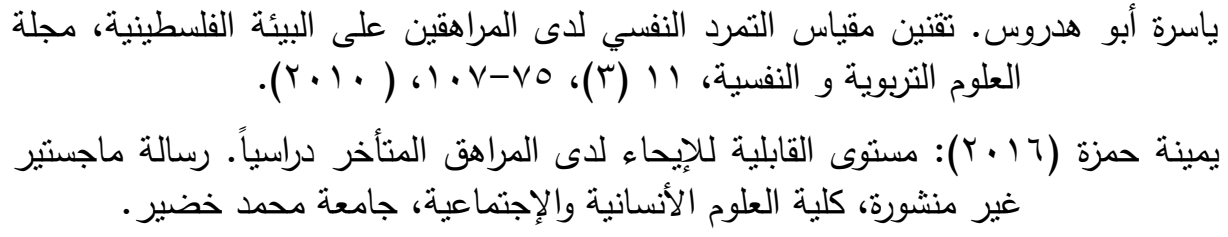

PSYCHOLOGICAL REBELLION AND ITS

\title{
RELATION TO SUGGESTIBILITY IN A SAMPLE OF SLUM AREAS CHILDREN
}

\section{Mai A. Abd-Elradi(1);Mohamed R. Al-Behairy ${ }^{(2)}$;}

Elshaimaa B. Amer ${ }^{(3)}$ and Eman S. Shahin ${ }^{(4)}$

1) Faculty of Post-Graduate Childhood Studies, Ain Shams University

2) Institute of Environmental studies and Research, Ain Shams University 3) Faculty of Women, Ain Shams University

\begin{abstract}
Study aimed: The current study aimed to examine the relationship between psychological rebellion and the suggestibility among children of slum areas and to reveal the differences between children of slums and children of planned areas in both psychological rebellion and suggestibility. Method and procedures: The researcher used the descriptive comparative approach, And The study sample consisted of (50) a boy and a girl from slum areas and (50) a boy and a girl from planned areas with mean age (10. 180), they completed the psychological rebellion scale (by researcher), the suggestibility scale (by researcher) and the Assiut University scale for non-verbal intelligence (Prepared by: Taha Al-Mestkawi, 2000). The results:

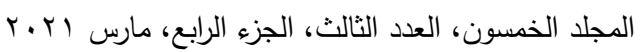

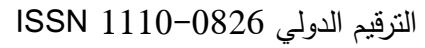




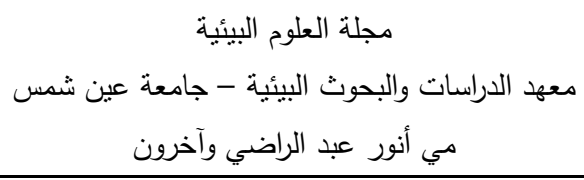

showed that there is a statistically significant positive relation between the psychological rebellion of children and the suggestibility of children It also showed that there are differences statistically significant between children from slums and children from the planned areas on the scale of children's psychological rebellion favoring of children in slums, as well as the there are differences statistically significant between children From slum areas and children from planned areas on the scale of suggestibility to children, favoring children in slum areas.

Keywords: Psychological rebellion, suggestibility, children from slum areas. 